\title{
Etheno adducts: from tRNA modifications to DNA adducts and back to miscoding ribonucleotides
}

\author{
F. Peter Guengerich *D and Pratibha P. Ghodke
}

\begin{abstract}
Etheno (and ethano) derivatives of nucleic acid bases have an extra 5-membered ring attached. These were first noted as wyosine bases in tRNAs. Some were fluorescent, and the development of etheno derivatives of adenosine, cytosine, and guanosine led to the synthesis of fluorescent analogs of ATP, NAD ${ }^{+}$, and other cofactors for use in biochemical studies. Early studies with the carcinogen vinyl chloride revealed that these modified bases were being formed in DNA and RNA and might be responsible for mutations and cancer. The etheno bases are also derived from other carcinogenic vinyl monomers. Further work showed that endogenous etheno DNA adducts were present in animals and humans and are derived from lipid peroxidation. The chemical mechanisms of etheno adduct formation involve reactions with bis-electrophiles generated by cytochrome P450 enzymes or lipid peroxidation, which have been established in isotopic labeling studies. The mechanisms by which etheno DNA adducts miscode have been studied with several DNA polymerases, aided by the X-ray crystal structures of these polymerases in mispairing situations and in extension beyond mispairs. Repair of etheno DNA adduct damage is done primarily by glycosylases and also by the direct action of dioxygenases. Some human DNA polymerases $(\eta, k)$ can insert bases opposite etheno adducts in DNA and RNA, and the reverse transcriptase activity may be of relevance with the RNA etheno adducts. Further questions involve the extent that the etheno adducts contribute to human cancer.
\end{abstract}

Keywords: Etheno modification, Bis-electrophiles, Chemical carcinogens, DNA adducts, RNA adducts, Mutagenesis, Xray crystallography, Mass spectrometry, Enzyme kinetics

\section{Introduction}

Etheno adducts are interesting for a number of reasons. One of us was first introduced to these in the late 1970s, and both of us continue to work with these today. The most important four etheno adducts, at least with regard to issues of mutagenesis and cancer, are shown in Fig. 1. Note the numbering systems, which differ from the purines and pyrimidines. Some additional 5-membered exocyclic ring compounds of relevance are shown in Fig. 2.

\footnotetext{
*Correspondence: f.guengerich@vanderbilt.edu

Department of Biochemistry, Vanderbilt University School of Medicine, 638B Robinson Research Building, 2200 Pierce Avenue, Nashville, TN 37232-0146, USA
}

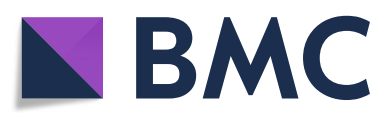

The history of etheno bases goes back to before either of us knew about them, to their discovery in tRNA. These are natural products. The history continues through organic synthesis and use in bioorganic chemistry and then their discovery as DNA adducts derived from work with chemical carcinogens. Detailed mechanisms of formation are discussed. Another important discovery was their presence as "endogenous" DNA adducts. The effects of the etheno adducts on DNA pairing have been investigated in detail, both in free oligonucleotides and within active sites of DNA polymerases. The etheno DNA adducts are repaired by specific enzymes. Finally, etheno adducts in RNA can be misread by DNA polymerases involved in reverse transcriptase activity.

(c) The Author(s). 2021 Open Access This article is licensed under a Creative Commons Attribution 4.0 International License, which permits use, sharing, adaptation, distribution and reproduction in any medium or format, as long as you give appropriate credit to the original author(s) and the source, provide a link to the Creative Commons licence, and indicate if changes were made. The images or other third party material in this article are included in the article's Creative Commons licence, unless indicated otherwise in a credit line to the material. If material is not included in the article's Creative Commons licence and your intended use is not permitted by statutory regulation or exceeds the permitted use, you will need to obtain permission directly from the copyright holder. To view a copy of this licence, visit http://creativecommons.org/licenses/by/4.0/ The Creative Commons Public Domain Dedication waiver (http://creativecommons.org/publicdomain/zero/1.0/) applies to the data made available in this article, unless otherwise stated in a credit line to the data. 

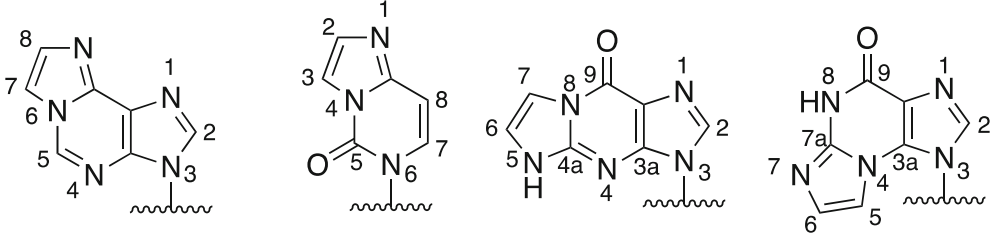

$1, N^{6}-\varepsilon-$ Ado

$3, N^{4}-\varepsilon-C y d$

$1, N^{2}-\varepsilon-$ Guo

$N^{2,3}-\varepsilon$-Guo

Fig. 1 The four major etheno bases. Numbering systems are shown. The modified bases may be in DNA or RNA

\section{Y-bases in tRNA}

tRNAs have a number of unusual bases, which appear to be involved in maintaining the stem-loop structures needed. A fluorescent base was found in yeast tRNA [5-7], and structures were characterized [8-11]. These structures (Fig. 3) are derivatives of $1, N^{2}-\varepsilon-$ Guo (Fig. 1). They have been found in tRNAs from animals, yeast, and archaebacteria but not eubacteria or in mitochondria or chloroplasts [12].

The biosynthesis of these etheno derivatives is complex and, in terms of metabolic strategies, expensive. A pathway for biosynthesis is shown in Fig. 4. The source of the extra two carbon atoms is pyruvate [14], and the catalysts involved are flavoproteins and radical $S$-adenosylmethionine (SAM) enzymes. The residual amino acid side chain (from methionine) is esterified and acetylated to form wybutosine (Fig. 4). Detailed proposals for formation of the imidazoline ring are presented in Fig. 5 [14-16].

\section{Etheno derivatives of cofactors}

In 1971 Kochetov et al. [17] reported that the reaction of 2-chloroacetaldehyde with 9-methyladenine and 1methylcytosine yielded the $N$-methyl derivatives of $1, N^{6}$ $\varepsilon$-Ado and 3,N $N^{4}-\varepsilon$-Cyd (Fig. 1). Leonard and his associates used 2-chloroacetaldehyde to prepare $1, N^{6}-\varepsilon$ Ado and $N^{3}, 4-\varepsilon$-Cyd under mildly acidic conditions [18]. The latter group then used this approach to prepare the etheno derivatives of $3^{\prime}$-AMP, 5'-AMP, 3',5'-cyclic AMP, ADP, and $\mathrm{NAD}^{+}$[19]. These derivatives were active as cofactors in a number of enzyme systems and allowed for the analysis of binding parameters and other properties (Fig. 6) [20-22].

Unpaired bases in rRNA could also be modified with 2-chloroacetaldehyde, with up to 16 of the 23 adenines reacting and retention of $80 \%$ of the biological activity [23].

\section{Modification of DNA by products of vinyl chloride and other olefins generates etheno adducts}

Vinyl chloride was found to produce unusual liver tumors in workers who handled this vinyl monomer in the polymer industry [24], and this cancer could be reproduced in rats [25]. Malaveille et al. [26] showed that the bacterial mutagenicity of vinyl chloride was dependent upon the addition of a liver microsomal system (containing cytochrome P450 (P450)) from rats, mice, or humans. Two of the suspected oxidation products of vinyl chloride, 2-chloroethylene oxide (vinyl chloride epoxide) and its rearrangement product 2-chloroacetaldehyde, were directly<smiles>Cn1cnc2c(=O)n3c(nc21)NC[C@@H]3O</smiles>

7-OH-1, $N^{2}$-ethano-Guo<smiles>Cn1cnc2c(=O)n3c(nc21)N[C@H](O)C3</smiles>

$6-\mathrm{OH}-1, N^{2}$-ethano-Guo<smiles>CC(=O)Cc1c[nH]c2nc3c(ncn3C(C)C)c(=O)n12</smiles>

Propanone-1, $N^{2}-\varepsilon-G$ uo

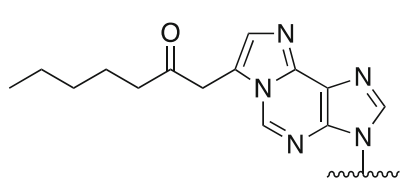

Heptanone-1, $N^{6}-\varepsilon$-Ado

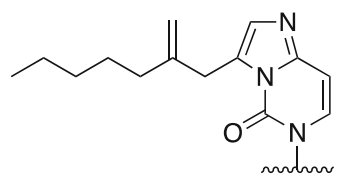

Heptanone-3, $N^{4}-\varepsilon$-Cyd

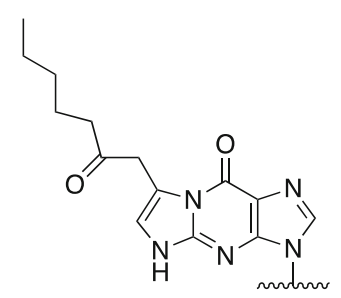

Heptanone-1, $N^{2}-\varepsilon$-Guo

Fig. 2 Other etheno derivatives reported in biological systems [1-4] 
<smiles></smiles>

Wyosine<smiles>Cc1nc2n(C)c3c(ncn3[18OH])c(=O)n2c1C</smiles>

7-Methylwyosine<smiles>Cc1cn2c(=O)c3ncn([Pb])c3[nH]c2n1</smiles>

4-Demethylwyosine<smiles>Cc1nc2[nH]c3c(ncn3[Pb])c(=O)n2c1C</smiles>

Isowyosine<smiles>CC(=O)NC(CCc1c(C)nc2n(C)c3c(ncn3[14CH3])c(=O)n12)C(C)=O</smiles>

Wybutosine<smiles>Cc1nc2[nH]c3c(ncn3[Pb])c(=O)n2c1CCC(N)C(=O)O</smiles><smiles>Cc1nc2n(C)c3c(ncn3[12CH2])c(=O)n2c1CCC(N)C(=O)O</smiles>

7-Aminocarboxypropylwyosine

Fig. 3 Wyosine and related tRNA bases containing etheno structures [12]

mutagenic [26], and both of these compounds reacted with free Ado to form $1, N^{6}-\varepsilon$-Ado [27].

Laib and Bolt [28] reported that $1, N^{6}-\varepsilon$-Ado was formed in the incubation of vinyl chloride with rat liver microsomes, poly-Ado, and NADPH, and $1, N^{6}-\varepsilon$ dAdo and $3, N^{4}$ - $\varepsilon$-dCyd were formed in vitro under similar conditions [29]. $1, N^{6}-\varepsilon$-dAdo, $1, N^{6}-\varepsilon$-Ado, 3, $N^{4}-\varepsilon$-dCyd, and $3, N^{4}-\varepsilon-C y d$ were identified as DNA and RNA adducts in livers of rats treated with ${ }^{14} \mathrm{C}$-vinyl chloride [29, 30].
Sattsangi et al. [31] had described the reaction of 2chloracetaldehyde with guanosine in the synthesis of $1, N^{2}$ - $\varepsilon$-Guo. The synthesis of $N^{2}, 3-\varepsilon$-Guo required blocking the $\mathrm{O} 6$ atom. Kúsmierek and Singer [32] also reported that $1, N^{2}-\varepsilon$-dGuo was formed in polynucleotides and DNA treated with 2-chloroacetaldehyde.

Both 2-choroethylene oxide and its rearrangement product 2-chloroacetaldehyde are capable of reacting with nucleic acids to generate etheno adducts (Fig. 7, Table 1) [27]. Gwinner et al. [36] reported that 2,2' -

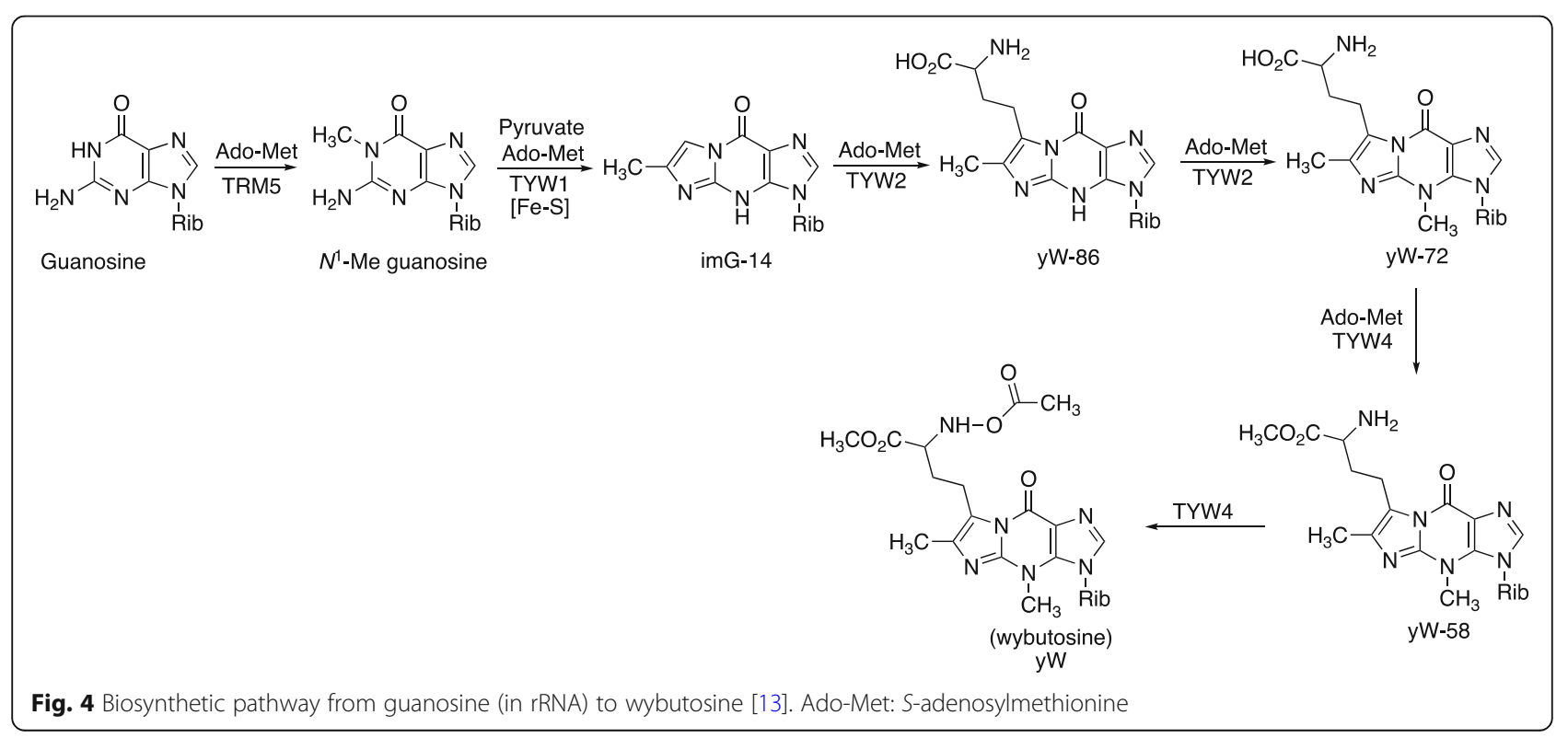



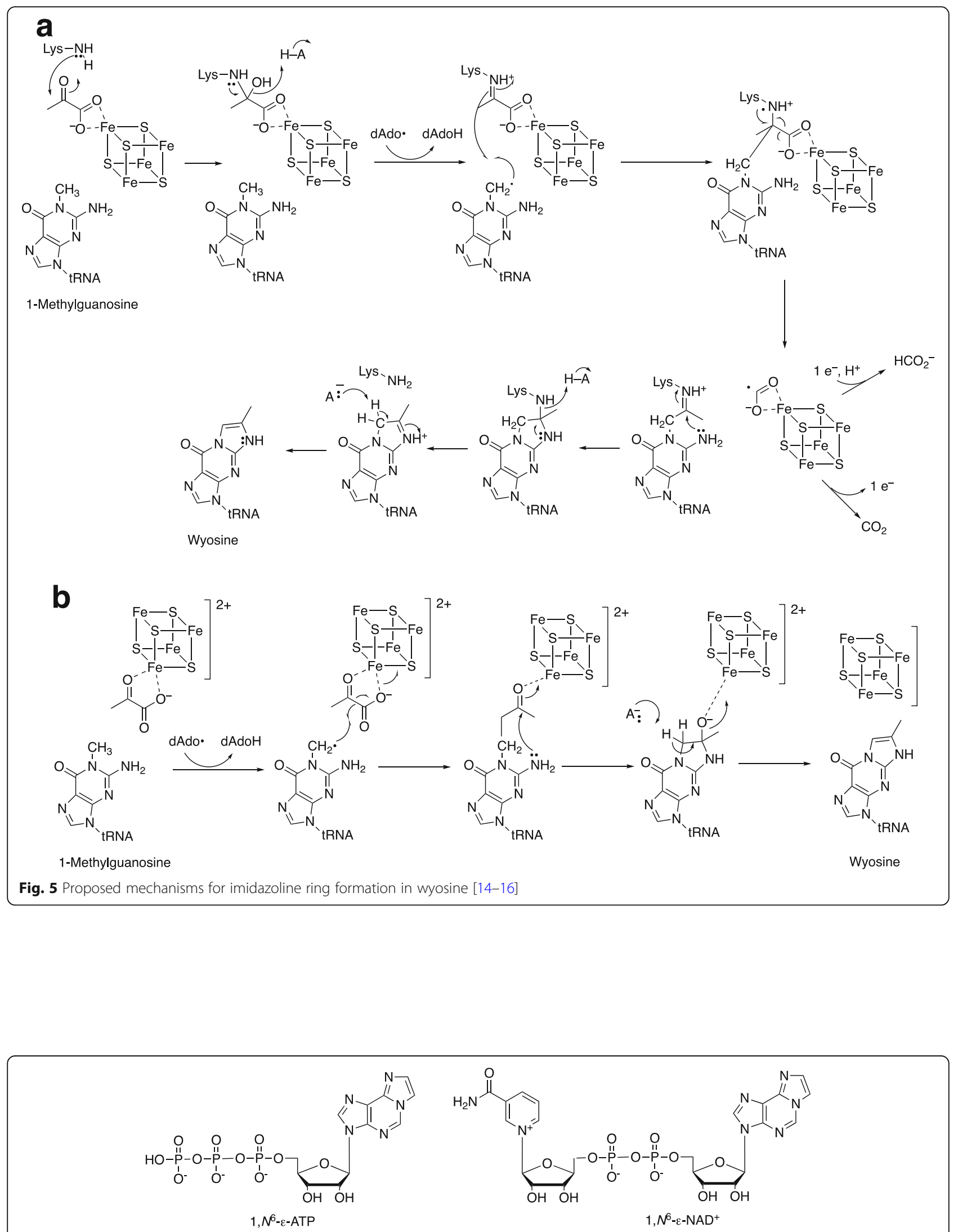

Fig. $61, N^{6}-\varepsilon$-Ado derivatives of ATP and $N A D^{+}[19-21]$ 


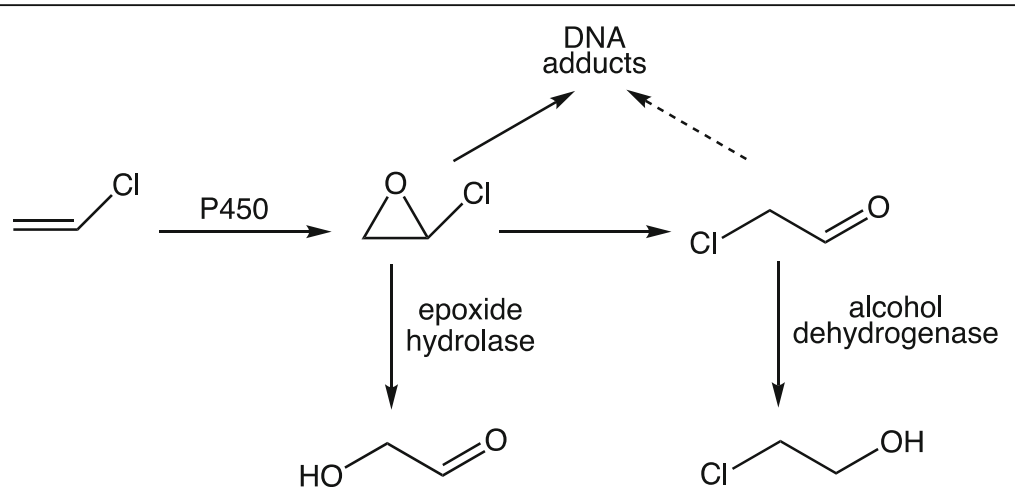

Fig. 7 Oxidation of vinyl chloride to 2-chlorooxirane (vinyl chloride epoxide), rearrangement to 2-chloroacetaldehyde, and reaction with DNA (and RNA). The enzymes epoxide hydrolase and alcohol dehydrogenase (plus NADH) were used to attenuate each of the products and ascertain which is the major one involved in binding [33, 34]

dichlorodiethyl ether, which is hydroxylated and decomposes to 2-chloroacetaldehyde, did not yield etheno DNA adducts or $N^{7}$-(2-oxoethyl) dGuo when given to rats nor did it produce the preneoplastic foci, a hallmark of vinyl chloride carcinogenesis. The results were congruent with in vitro results on the labeling of DNA by ${ }^{14} \mathrm{C}$-vinyl halides in microsomal reactions, with the epoxides and 2-haloacetaldehydes being quenched by the addition of enzymes (epoxide hydrolase and alcohol dehydrogenase) (Fig. 7) [33].

Other chemical carcinogens were found to generate etheno DNA and RNA adducts, as a result of generation of bis-electrophiles (Fig. 8). Labeled $1, N^{6}-\varepsilon$-Ado and 3, $N^{4}$-E-Cyd were found in RNA of mice treated with ${ }^{14} \mathrm{C}$ ethyl carbamate [39], which is now understood to be oxidized to vinyl carbamate and then to the epoxide [39-41].

Acrylonitrile can be oxidized (by P450 2E1) to 2cyanoethylene oxide, which reacts with Ado to form 1, $N^{6}$-ع-Ado [42].

At least two nitrosamines can form etheno adducts. One is the epoxide derived from methyl, vinyl nitrosamine, which reacted with Ado to form $1, N^{6}$-e-Ado [37]. A nucleophilic attack (adenosine) on the epoxide also generates methyl diazohydroxide, a methylating agent (which yielded $N^{7}$-methyl dGuo). Hecht et al. [3] reported that the reaction of $\alpha$-hydroxy- $N$-nitroso piperidine with DNA generated a 7-(2-oxopropyl) derivative of $1, N^{2}-\varepsilon$-dGuo. This product, proposed to be formed from 4-oxo-2-pentenal, has relevance to subsequent work on lipid peroxidation.

The characterization of human P450 2E1 allowed a number of cancer suspects to be examined as substrates. The enzyme was found to catalyze the oxidation of vinyl chloride, vinyl bromide, acrylonitrile, and vinyl carbamate to form $1, N^{6}$ - $\varepsilon$-Ado (with Ado as a trap), presumably via the epoxides [43]. Ethylene dichloride and ethylene dibromide also yielded $1, N^{6}$ - $\varepsilon$-Ado, presumably via oxidation to the 2-haloacetaldehydes. Subsequent studies in this [43] and several other laboratories have identified P450 2E1 as the major catalyst involved in the oxidation of small chemical carcinogens, especially vinyl monomers.

\section{Endogenous etheno DNA adducts}

In the course of developing sensitive assays for DNA adducts, the Swenberg laboratory reported that $N^{2}, 3-\varepsilon-$

Table 1 DNA Adducts Formed in Reaction with 2-Chlorooxirane (Vinyl Chloride Epoxide)

\begin{tabular}{|c|c|c|c|}
\hline Adduct $^{a}$ & Yield with $10 \mathrm{mM}$ 2-chlorooxirane, pmol ( $\mu \mathrm{mol}$ of DNA base) ${ }^{-1}$ & Method & Ref \\
\hline$\overline{N^{7} \text {-(2-oxoethyl)Gua }}$ & 10,000 & HPLC/fluorescence & {$[34]$} \\
\hline $1, N^{6}-\varepsilon-d A d o$ & 500 & HPLC/fluorescence & [34] \\
\hline HO-ethanoGua & 24 & HPLC/MS/MS & [35] \\
\hline HO-ethanodGuo & 29 & HPLC/MS/MS & [35] \\
\hline$N^{2}, 3-\varepsilon-G u a$ & 16 & HPLC/fluorescence & [1] \\
\hline $3, N^{4}-\varepsilon-d C y d$ & 7 & HPLC/fluorescence & {$[35]$} \\
\hline \multirow[t]{2}{*}{$1, N^{2}-\varepsilon-G u a$} & $\sim 1^{b}$ & HPLC/fluorescence & [1] \\
\hline & 2.5 & HPLC/MS/MS & {$[35]$} \\
\hline
\end{tabular}

${ }^{\mathrm{a}}$ The name of the adduct indicates whether the base or deoxyribonucleoside was assayed

b In other work, a $15 \mathrm{mg} \mathrm{mL}^{-1}$ concentration of herring sperm DNA was used instead of $5 \mathrm{mg}$ of calf thymus DNA mL ${ }^{-1}$ in references [34], and a value of 6.5 pmol $(\mu \mathrm{mol} \text { of DNA base })^{-1}$ was obtained [1] 


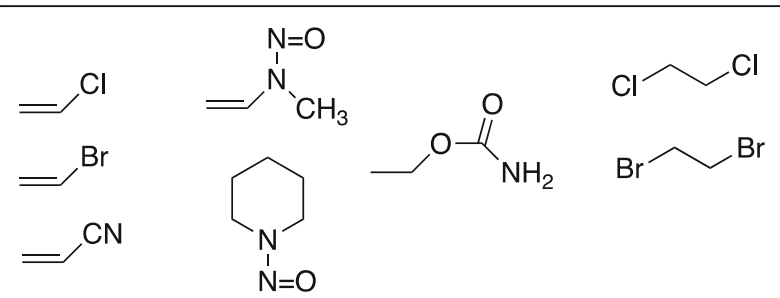

Fig. 8 Chemicals known to lead to the formation of etheno adducts. The vinyl monomers undergo epoxidation to generate biselectrophiles [37]. N-Nitrosopiperidine is a-hydroxylated to yield a product that breaks down to 4-oxo-2-pentenal and reacts to form propanone-1, $N^{2}-\varepsilon(d)$ Guo [3] (Fig. 2). The two ethylene dihalides can be hydroxylated to the gem-halohydrins, which then release $\mathrm{HCl}$ or $\mathrm{HBr}$ to yield 2-haloacetaldehydes [38]

dGuo was present in the DNA of livers of untreated rats [44]. This result was surprising in light of the growing number of vinyl monomers and related compounds that had been shown to form etheno adducts. The Bartsch and Chung laboratories showed that $1, N^{6}-\varepsilon$-dAdo and 3, $N^{4}$ - $\varepsilon$-dCyd could be generated during unsaturated lipid peroxidation [45-47]. The endogenous levels of some of the etheno DNA adducts are on the order of magnitude of other modified DNA bases associated with oxidative damage [44]. Further, levels of damage have been shown to be greatly increased (2- to 45 -fold) by high fat diets and diseases of chronic inflammation [48].

Mechanisms of formation of etheno adducts are complex and can involve hydroperoxides, keto enols, and epoxides (Figs. 9 and 10). The proposed mechanism (Fig. 10) begins with carbinolamine/Schiff base formation with exocyclic amines, followed by reaction of a ring amine with the "second" electrophile (Fig. 10) [4, 49-54]. Some of the "branched" etheno DNA adducts, a 3-substituted 2-hexanone derivative of $3, N^{4}$ - $\varepsilon$-dCyd [55] and a 1 , $N^{2}$ - $\varepsilon$-dGuo derivative formed by trans-4-hydroxynonenal [56] have been shown to produce mutations in cells, as well as misinsertions in reactions catalyzed by individual DNA polymerases $[57,58]$. Some of the etheno adducts derived from lipid peroxidation have been shown to lead to DNA interstrand crosslinks $[59,60]$.

A summary of analyses of etheno DNA adducts in untreated rats and humans is presented in Table 2. As can be noted, there is considerable variation, due in part to different methods of analysis. Most of the levels are a few adducts per $10^{8}$ nucleotides. It should be noted that $1, N^{2}-\varepsilon$-dGuo has not been measured in tissue samples. It was not detected in the rat liver work of Morinello et al. [64], even in vinyl chloride-exposed rats, and was considered unrelated to the tumors. However, the base (1, $N^{2}$ - $\varepsilon$-Gua) is excised by base excision repair and can be detected in human urine [71]. Levels of excretion were $\sim 2$-fold higher in smokers than non-smokers.

\section{Chemical mechanisms of formation of etheno adducts}

Reactions of bis-electrophiles can be complex in that there are two sites of reaction with nucleophiles (e.g., DNA). Moreover, there may be a series of possible electrophiles due to instability of some, e.g. epoxides.

As already mentioned (Fig. 7), early studies with vinyl chloride and vinyl bromide showed that epoxide hydrolase was more effective in attenuating the binding of radioactivity from either vinyl halide to DNA in microsomal incubations [33], implicating 2-haloethylene oxides as the reactive species, instead of 2haloacetaldehydes. These results were opposite of those experiments in which protein binding was measured

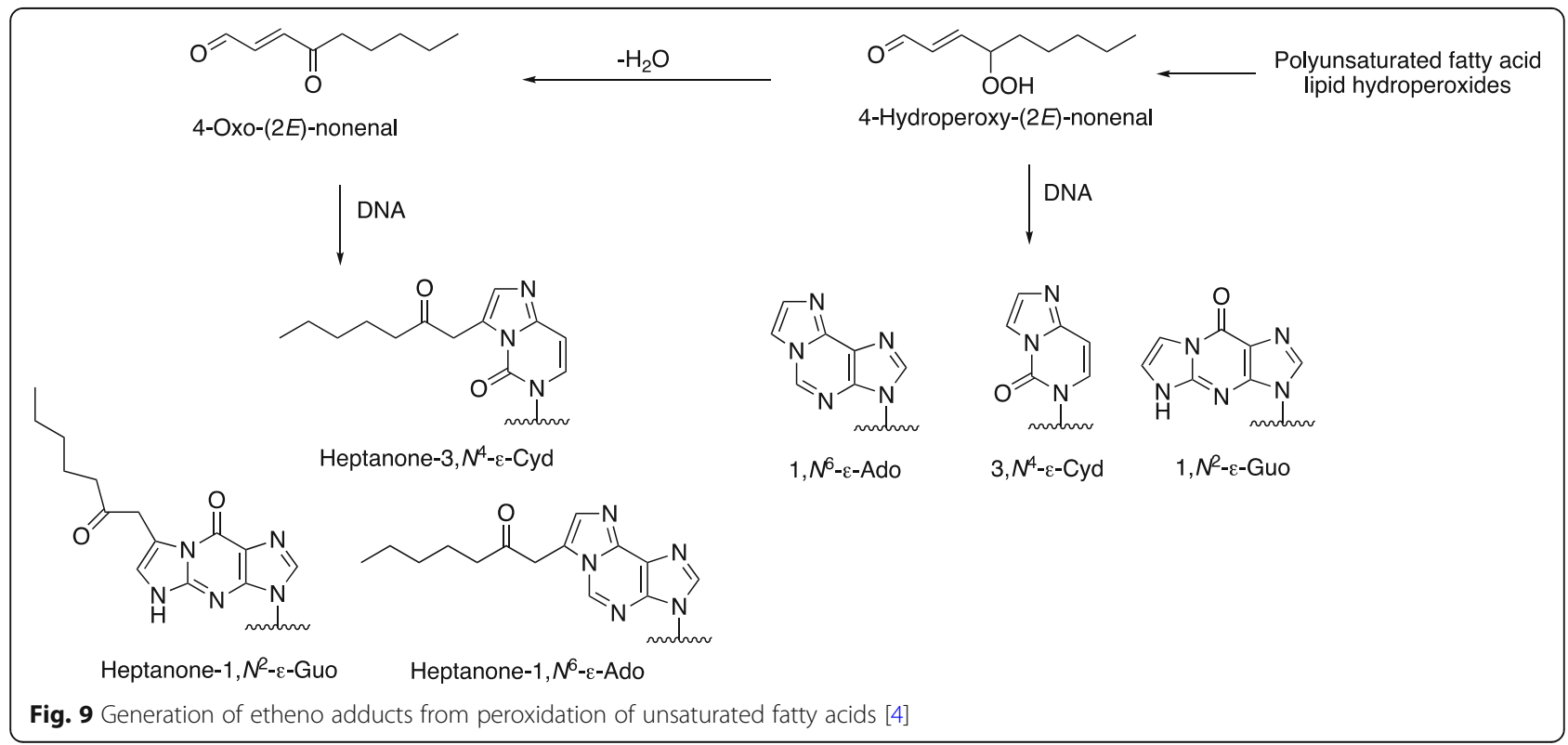




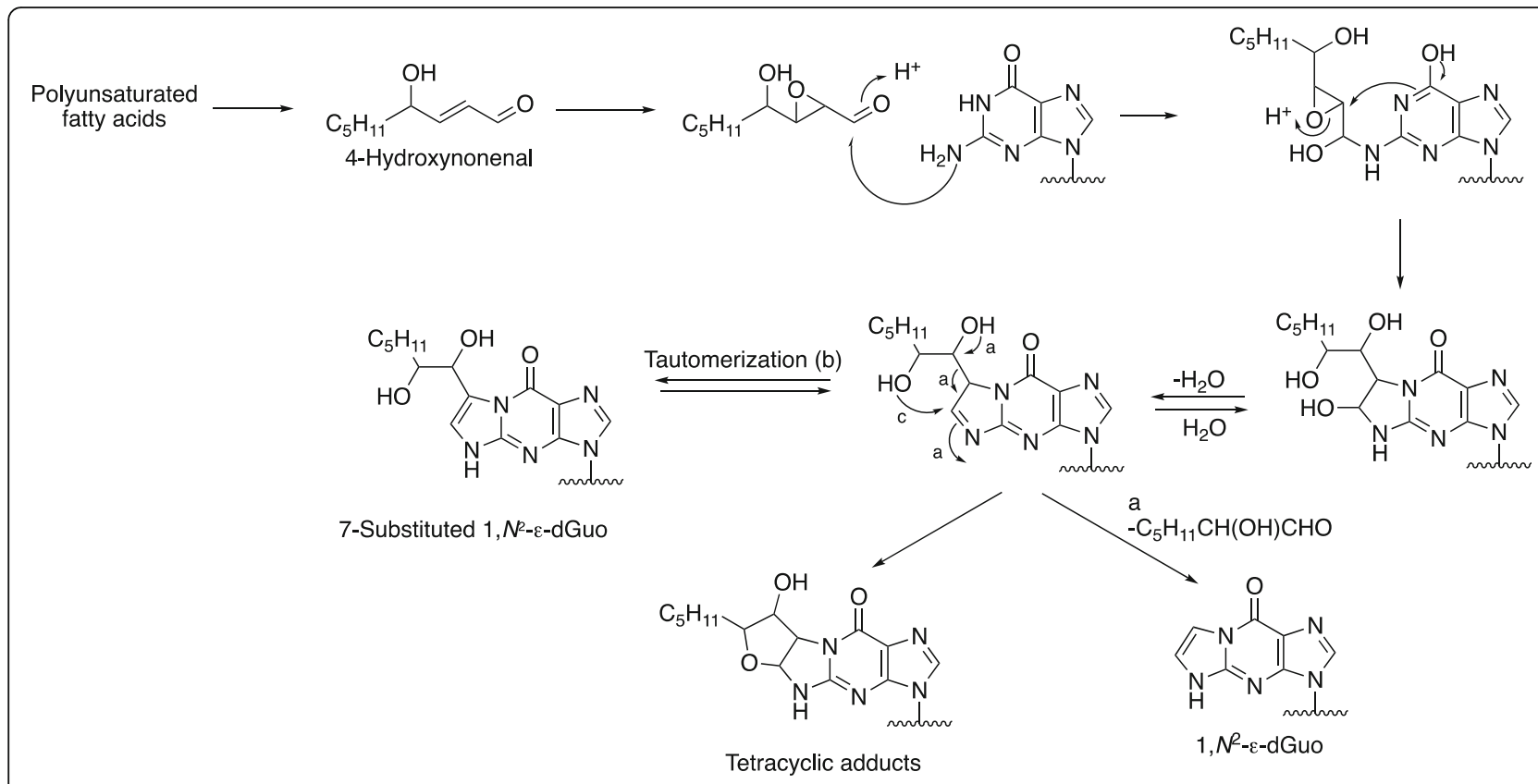

Fig. 10 Reaction of dGuo with 4-hydroxynonenal epoxide leading to $1, N^{2}-\varepsilon$-dGuo and branched derivatives [49, 50]

[72] and can be rationalized in the context of hard (DNA) and soft (thiol) nucleophiles reacting with different electrophiles.

The reaction of $N^{6}$-methylAdo with 2-chlorooxirane was two orders of magnitude faster than with 2chloroacetaldehyde [38]. The yields of $1, N^{6}-\varepsilon$-dAdo and $N^{2}, 3-\varepsilon$-dGuo were also two orders of magnitude higher with 2-chlorooxirane than 2-chloroacetaldehyde, and (as in Fig. 7) epoxide hydrolase was more effective than alcohol dehydrogenase in attenuating the levels of both adducts formed in DNA in incubations with vinyl chloride and rat liver microsomes [1, 34].

Mechanisms for the reaction of 2-haloethylene oxides with Ado (Fig. 11) and Cyd (Fig. 12) have been elucidated using ${ }^{13} \mathrm{C}$ NMR spectroscopy [38]. The approach involved the slow generation of 2-bromoethylene oxide in situ from 2,2-dibromoethanol at $\mathrm{pH} 9.2$. The ${ }^{13} \mathrm{C}$ labeling patterns with the $1, N^{6}-\varepsilon$-Ado and $3, N^{4}-\varepsilon$-Cyd

Table 2 Levels of Measured Endogenous Etheno DNA Adducts (see also [61])

\begin{tabular}{|c|c|c|c|c|c|c|c|}
\hline \multicolumn{2}{|c|}{ DNA Source } & \multicolumn{4}{|c|}{ Adducts $/ 10^{8}$ nucleotides } & \multirow[t]{2}{*}{ Method } & \multirow[t]{2}{*}{ Reference } \\
\hline & & $1, N^{6}$ - $\varepsilon$-dAdo & $3, N^{4}-\varepsilon-\mathrm{dCyd}$ & $1, N^{2}$ - $\varepsilon$-dGuo & $N^{2}, 3-\varepsilon$-dGuo & & \\
\hline \multirow[t]{9}{*}{$\overline{R a t}$} & Liver & $0.10-0.12$ & $0.10-0.12$ & & & Immunoaffinity ${ }^{32} \mathrm{P}$ labeling & [47] \\
\hline & Liver & & & & $18-23$ & GC/MS & [47] \\
\hline & Liver & 120 & 560 & & & HPLC/ ${ }^{32}$ P labeling & [62] \\
\hline & Liver & $0.011-0.012$ & $0.016-0.017$ & & & Immunoaffinity ${ }^{32} \mathrm{P}$ labeling & [63] \\
\hline & Lung & $0.4-0.5$ & $1.8-3.8$ & & & Immunoaffinity $/^{32} \mathrm{P}$ labeling & [63] \\
\hline & Kidney & $0.7-0.8$ & $2.1-2.8$ & & & Immunoaffinity ${ }^{32} \mathrm{P}$ labeling & [63] \\
\hline & Lymphocytes & 1.1 & 1.2 & & & Immunoaffinity ${ }^{32} \mathrm{P}$ labeling & [63] \\
\hline & Hepatocytes & & & & 1.4 & Immunoaffinity/GC/MS & [64] \\
\hline & Hepatocytes & & & $N^{a}$ & & Immunoaffinity/GC/MS & [65] \\
\hline \multirow[t]{5}{*}{ Human } & Hepatocytes & & & & 2.0 & LC/MS & [66] \\
\hline & Oral cells & 0.77 & 0.61 & & & LC/MS & [67] \\
\hline & Placenta & $74-84$ & & & & LC/MS & [68] \\
\hline & Placenta & 1.1 & & & & LC/MS & [69] \\
\hline & Pancreas & 1.8 & 1.2 & & & Immunoaffinity $/^{32} \mathrm{P}$ labeling & [70] \\
\hline
\end{tabular}


<smiles>Cc1nc2c(N)[n+](CC=O)cnc2n1-c1cn([Pb])c2ncnc(N)c12</smiles>

Fig. 11 Mechanism of reaction of a 2-halooxirane with Ado to form $1, N^{6}-\varepsilon$-Ado [38]. * indicates a ${ }^{13} \mathrm{C}$ label

showed that the initial reaction is of a ring nitrogen $(\mathrm{N} 1$ of Ado or N3 of Cyd) with the unsubstituted methylene carbon of the 2-haloethylene oxide [38]. Similar studies were done with Guo (Fig. 13) [1]. As with Ado and Cyd, the formation of $1, N^{2}-\varepsilon$-Guo is explained by the reaction of the (ring) N1 nitrogen on the methylene carbon of the 2-haloethylene oxide. However, the formation of $N^{2}$, 3 - $\varepsilon$-dGuo is more complex, and we concluded that the N3 (ring) nitrogen of dGuo reacts first with the halogensubstituted carbon of the 2-haloethylene oxide, with subsequent reaction of the (formed) aldehyde with the exocyclic (N2) nitrogen, followed by dehydration of the carbinolamine [1].

When 2-bromoacetaldehyde reacted with Guo, the ${ }^{13} \mathrm{C}$ labeling pattern indicated that the initial reaction was that of the aldehyde to form a Schiff base, followed by attachment of the $\mathrm{N} 1$ atom to form $1, N^{2}-\varepsilon$-Guo or the $\mathrm{N} 3$ atom to form $N^{2}, 3-\varepsilon$-Guo (Fig. 14) [73]. Kúsmierik and Singer [74] had reported that the reaction of 2chloroacetaldehyde with Ado or Cyd yielded quasi-stable carbinolamine intermediates ("hydrates"). The reaction of dGuo with glycidaldehyde to form $1, N^{2}-\varepsilon$-dGuo also proceeds via initial Schiff base reaction of the 1-amino group with the aldehyde [75].

We conclude that 2-haloethylene oxides are much more reactive than 2-haloacetaldehydes in reacting with DNA and RNA (Fig. 7). The results have biological relevance in that other chemicals that can generate 2- haloacetaldehydes after metabolism are not very carcinogenic [36] (Fig. 7). Treatment of DNA with 2-chlorooxirane yields a series of products, including 7-hydroxyethanodGuo, a stable hemiaminal (Fig. 2). The products were formed in the order $N^{7}$-(2-oxoethyl) dGuo $>>1, N^{6}-\varepsilon$-dAdo $>7$-hydroxyethano dGuo $>N^{2}, 3-\varepsilon$-dGuo $>3, N^{4}-\varepsilon$-dCyd $>1$, $N^{2}$-E-dGuo (Table 1) [35].

In the course of studies on the mechanisms of formation of $1, N^{2}-\varepsilon-(\mathrm{d})$ Guo and $N^{2}, 3-\varepsilon-(\mathrm{d})$ Guo [1], some anomalous behavior was noted when isotopic labeling studies were attempted with deuterium. The $\mathrm{H}-5$ proton of $N^{2}, 3-\varepsilon$-Guo was lost upon heating under mildly acidic conditions and explained the inability to prepare $\left[5-{ }^{2} \mathrm{H}\right]$ $N^{2}, 3-\varepsilon$-Guo from $\mathrm{ClC}^{2} \mathrm{H}_{2} \mathrm{CHO}\left(\mathrm{ClCD}_{2} \mathrm{CHO}\right)$. The $\mathrm{H}-5$ proton of $N^{2}, 3-\varepsilon$-Guo and the $\mathrm{H}-7$ proton of $1, N^{2}-\varepsilon$-Guo were selectively exchanged at either $\mathrm{pH} 7.7$ or 9.2. Mechanisms involving tautomeric exchange have been proposed [1]. Some of these results may explain sensitivity to acid and base in early studies on the tRNA Y-bases (vide supra, Fig. 3) [7, 9].

\section{Effect of etheno adducts on oligonucleotide structures}

Some of the early work involved treatment of tRNA with 2-chloroacetaldehyde [23] but the results were rather non-descript. An interesting finding was the reaction of chloroacetaldehyde with Z-(left-handed) DNA [76]; adenines (syn conformation) preferentially reacted<smiles></smiles>

Fig. 12 Mechanism of reaction of a 2-halooxirane with Cyt to form $3, N^{4}-\varepsilon$-Cyt [38]. * indicates a ${ }^{13} \mathrm{C}$ label 


\section{A}

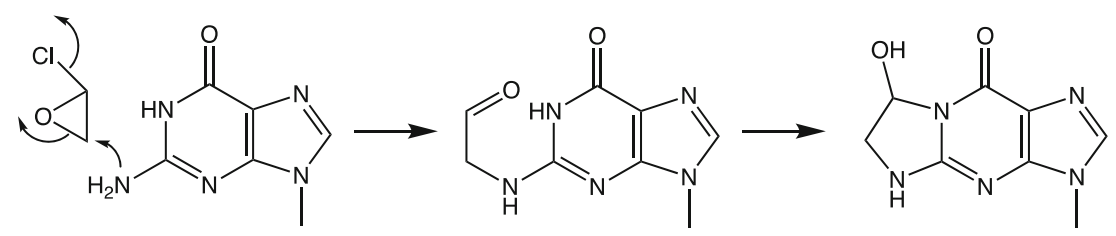

B

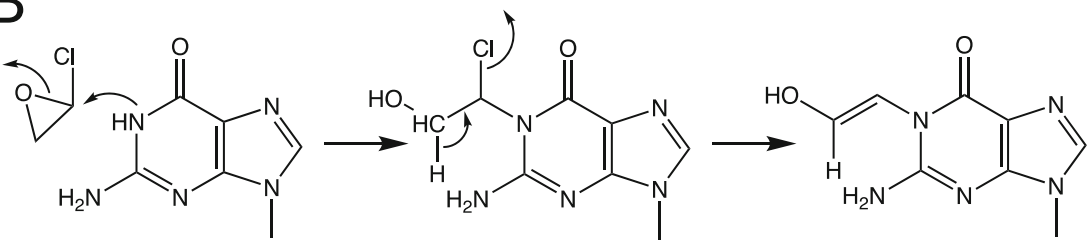<smiles>CCCCc1cn2c(=O)c3ncn(C)c3nc2[nH]1</smiles>

C

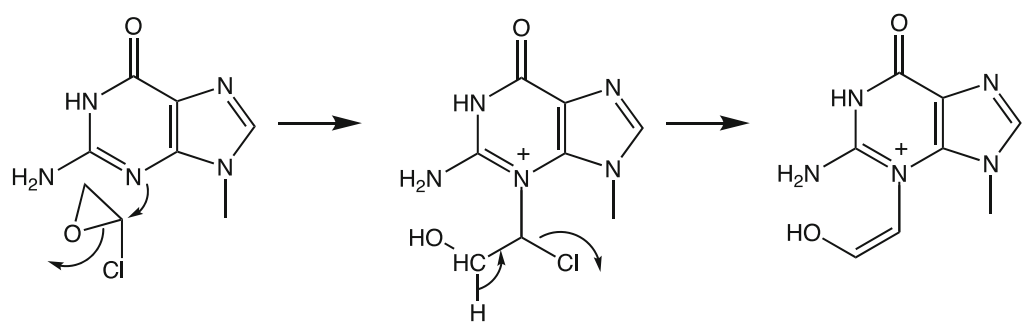

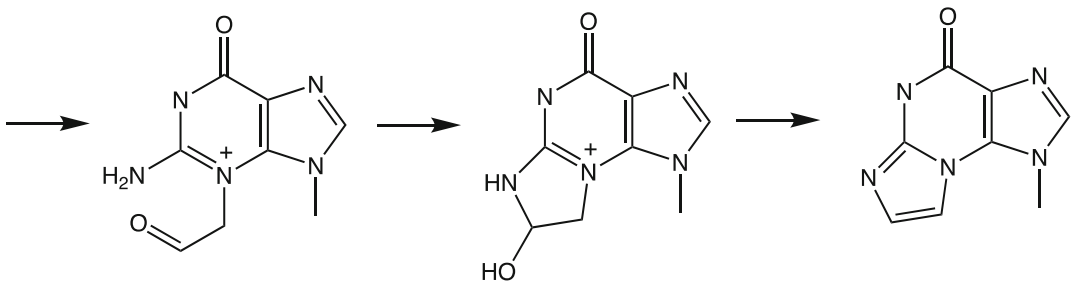

Fig. 13 Mechanism of reaction of 2-chlorooxirane with Guo to form a 7-OH-1, $N^{2}-\varepsilon-G u o$, b $1, N^{2}-\varepsilon-G u o$, and $\mathbf{c} N^{2}, 3-\varepsilon-G u o$ [1]

compared to cytosines (although etheno adducts were not characterized). In the reaction of 2chloroacetaldehyde with model polynucleotides, hydrogen bonding in double-stranded structures was important in the formation of $1, N^{2}-\varepsilon$-Gua [32]. The formation of $N^{2}, 3-\varepsilon$-Gua was relatively independent of whether the DNA was single- or double-stranded.

In 15-mer oligomeric duplexes, the pairing of $3, N^{4}-\varepsilon$ dCyd opposite dGuo, not surprisingly, destabilized the helix but not as much as a T:G mispair [77].

Apparently only two X-ray crystal structures have been published with etheno adducts present, and both are self-complementary. One has $1, N^{6}-\varepsilon$-dAdo:dGuo pairing
[78] and the other has $3, N^{4}-\varepsilon-\mathrm{dCyd}$ :dGuo pairing [79]. As expected, both have lost the normal base pairing.

More NMR studies have been published on pairing of etheno bases in oligonucleotides [80-89]. The majority of the NMR studies with $3, N^{4}-\varepsilon$-dCyd have it paired with $\mathrm{dGuo}$, with normal H-bonding blocked and a hydrogen bond involving the $\mathrm{O} 2$ atom of $3, N^{4}-\varepsilon$-dCyd and the N1 atom of dGuo, as in an X-ray structure, and similar to a T:G wobble pair. Both nucleotides in the $3, N^{4}-\varepsilon-\mathrm{dCyd}$ : dGuo pair were in the anti configuration but in a $3, N^{4}$ $\varepsilon$-dCyd:dThd pair the $3, N^{4}-\varepsilon$-dCyd lesion was syn and $\mathrm{dThd}$ was anti [80]. The alignment of $1, N^{6}-\varepsilon$-dAdo with dThd was nonplanar [85]. In a $1, N^{6}-\varepsilon$-Ado:dGuo pair 


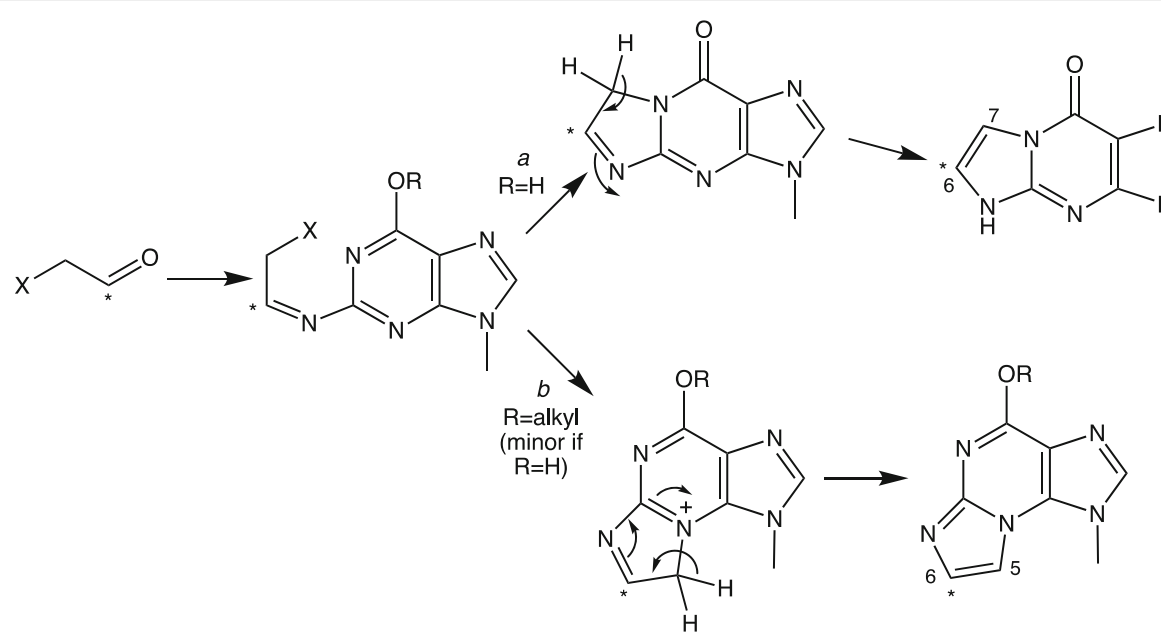

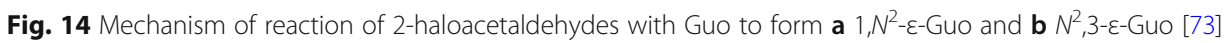

the $1, N^{6}$-ع-Ado was syn but dGuo was anti [86], as in the crystal structure [78].

Several NMR studies of $1, N^{2}-\varepsilon$-dGuo oligonucleotides have been published, at varying $\mathrm{pH}$ values [87-89]. The results are indicative of Hoogsteen pairing and a blend of conformations at neutral $\mathrm{pH}$. A structure with $1, N^{2}-\varepsilon-$ dGuo opposite a 1-base deletion showed increased duplex stability and can be considered as supportive of the tendency of $1, N^{2}-\varepsilon$-dGuo to cause - 1 frameshifts [90].

$1, N^{6}-\varepsilon$-Ado and $3, N^{4}-\varepsilon$-Cyd have been positioned in ribooligonucleotides and shown to cause destabilization of complexes with RNA and DNA complements [91].

\section{Interactions of etheno DNA adducts with DNA polymerases: structural and functional studies}

One of the most interesting aspects of studying DNA adducts is understanding the details of how an individual lesion causes miscoding. This has been a long-term goal but is not an easy one to accomplish, for a number of reasons.

The synthesis of oligonucleotides containing an adduct at a specific site can be problematic. The general approach is to prepare the modified base as a nucleoside and insert it using chemical synthesis. The adduct must be stable to the conditions of protection and deprotection. The oligonucleotide containing the adduct must be stable and also be very pure, especially if introduced into a cellular system, where the progeny of impurities are probably not discernible.

The question arises as to what to look at for miscoding. There is attraction to the use of a cellular system, as first developed by Essigmann and his associates in 1984 [92]. However, there are a number of aspects to consider. Should one use bacterial or mammalian cells? The presence of DNA repair systems can be problematic, in terms of attenuating responses (but cells with repair deficient backgrounds may be useful). There is also the issue, generally ignored, that almost all of the studies in this area have been "extra-chromosomal," i.e. the vectors (plasmids) may not be copied in the same manner as endogenous DNA adducts due to the use of different polymerases and accessory factors (for an exception see our work with $1, N^{2}-\varepsilon$-dGuo in [93]). Escherichia coli has five DNA polymerases and humans have at least 19 with some kind of polymerization activity, so how does one discern which is involved? One way is to compare in vitro assay results with different (purified) polymerases, i.e. specificity constants $\left(k_{\text {cat }} / K_{\mathrm{m}}\right)$. At the cellular level, it is now relatively easy to use CRISPR systems to make mammalian cell lines deficient in each polymerase and then compare mutation frequencies.

In order to define details of miscoding at a biochemical level, it is necessary to use individual DNA polymerases. In the early work, the use of viral, bacterial, or archaebacterial polymerases was popular but might not have been reflective of eukaryotic systems. Today most of the attention has been given to the so-called translesion synthesis (TLS) DNA polymerases (pols), especially the human ones (in the Y-Family, i.e., $\eta, \mathrm{l}, \kappa, \operatorname{ReV} 1$ ). There are two major approaches to understanding the actions of DNA polymerases, functional and structural.

Functional assays are largely focused on enzyme kinetics. Most of the work is with insertion into primers bound to templates containing an adduct, but some studies are done with dNTP extension past templateDNA adduct:primer mispairs. If the DNA adduct is very blocking, then steady-state kinetics analysis may be appropriate. However, in some cases it is preferable to use pre-steady-state kinetic analysis, especially if burst kinetics are observed [94].

Defining what the products are may not be trivial, as emphasized in our study with Sulfolobus solfataricus Dpo4 and $1, N^{2}-\varepsilon$-dGuo (Fig. 15) [90] (vide infra). There 


\section{5' GGGGGCGATGCTCGTAAGGATTC3' \\ 3' CCCCCGCTACGAGCATTCCTAAG1, $\boldsymbol{N}^{2}-\varepsilon-\mathrm{GCACT} 5$ '}

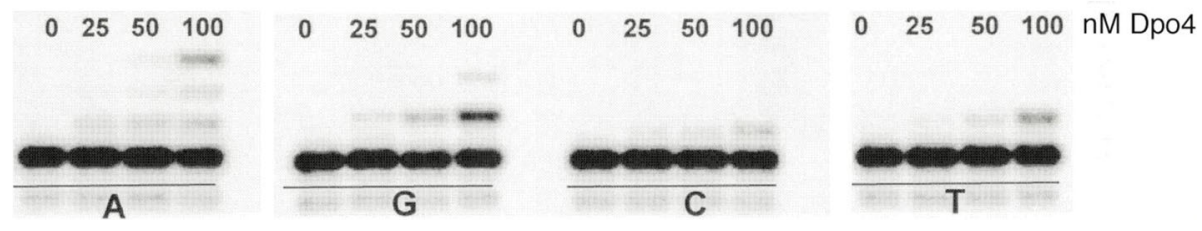

Fig. 15 Incorporation of dNTPs across from $1, N^{2}-\varepsilon-d G u o$ in a primer and extension beyond. The indicated primer template complex was incubated with the DNA polymerase Dpo4 and each dNTP $(A, G, C, T)$. The primer contained a $5^{\prime}-{ }^{32} \mathrm{P}$ label, and the products of each reaction was analyzed by denaturing gel electrophoresis [90]

are several approaches to defining the products of polymerase extension of primer:template complexes, which can be complex [95]. One is LC-MS sequence analysis (Fig. 16), which is relatively straightforward and still remains the method of choice in our own laboratory $[90,96,97]$. Others are the "REAP" and "CRAB" methods developed by Essigmann's laboratory [98]. The last, which has become feasible in recent years, is total sequencing [99].

The other aspect, structure, involves X-ray crystallography, which has proven to be very feasible for TLS DNA polymerases and DNA adducts. The only realistic

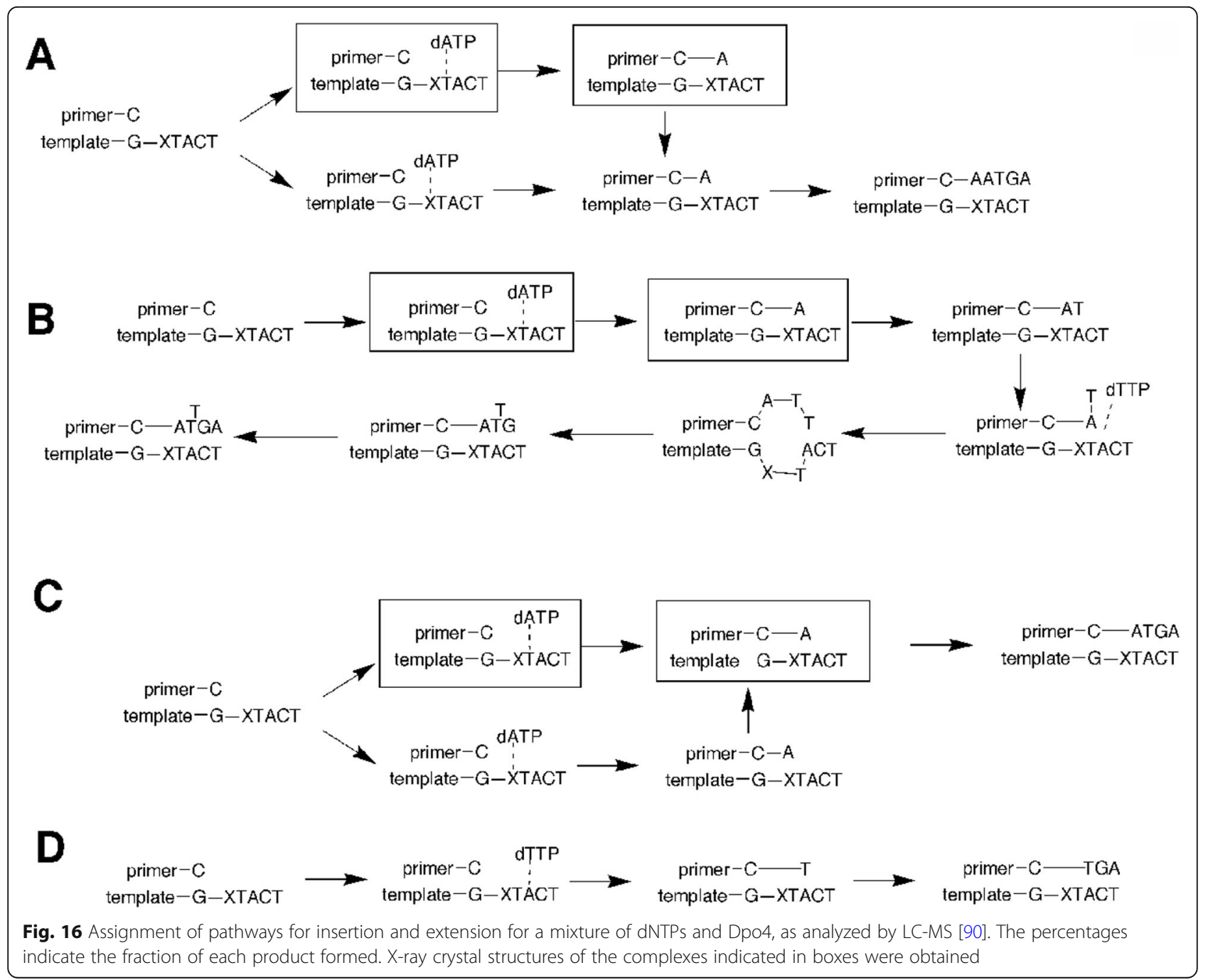


bacterial DNA polymerases for crystallography have been pol I, II, and IV [100-102]. Pol III and pol V, although they can have roles with DNA adducts, are too complex. The Y-Family TLS polymerase $S$. solfataricus Dpo4 has been popular as a model. Many structures of the core elements of human pol $\eta, \mathrm{l}$, and $\mathrm{\kappa}$ with adducts have now been reported, and in many cases the details have been quite revealing about mechanisms. Structural studies with the replicative DNA pols $\delta$ and $\varepsilon$ (and $E$. coli pol III and V) are not very realistic due to the number of subunits. Although pol $\beta$ has been a popular model for studies, this is really a gap-filling DNA polymerase and its relevance in studies on primer extension (or even insertion with a gap opposite a DNA adduct) is questionable.

The final point to make is that different polymerases may vary in terms of how they deal with a single DNA adduct. This is exemplified in work with $O^{6}$-methyl dGuo $[103,104]$ and in the case of $1, N^{2}-\varepsilon$-dGuo (Table 3).

Relatively few studies have been done with $3, N^{4}-\varepsilon$ dCyd. E. coli pol I (Klenow fragment) inserted dAMP and dTMP opposite $3, N^{4}-\varepsilon$-dCyd [109]. The same misinsertions were seen with mammalian pol $\alpha, \beta$, and $\delta$ [110] and in cellular E. coli and monkey kidney cells [111]. To our knowledge, no polymerase crystal structures with $3, N^{4}-\varepsilon$-dCyd have been reported, only those with a modified oligonucleotide in the absence of polymerase [79].

With regard to $1, N^{6}-\varepsilon$-dAdo, Singer's laboratory reported that all four of the dNTPs could be incorporated opposite this lesion by E. coli pol I and that the results were influenced by the choice of polymerase and the sequence $[112,113]$. The bases Ade, Cyt, and Gua were all reported to be misinserted in various extrachromosomal cellular misincorporation systems [114-117]. Levine et al. [117] had reported that human pol $\eta$ was 100 -fold more active than pol $\mathrm{\kappa}$ in replication past $1, N^{6}-\varepsilon$-dAdo, and our laboratory found that replication past $1, N^{6}-\varepsilon$ dAdo was dominated by incorporation of purines (dAdo, dGuo) and by extensive -1 frameshifts (Fig. 17) [118]. Frameshifts are not generally observed in simple primerextension studies but are readily detected by LC-MS analysis $[90,118]$. X-ray crystal structures indicated that the incoming dATP and dGTP were not paired with 1,

Table $3 N^{2}, 3-\varepsilon-d G u o$ vs. 1, $N^{2}-\varepsilon$-dGuo $[90,105-108]$

\begin{tabular}{|c|c|c|c|c|c|c|c|c|}
\hline Polymerase & Template & $\begin{array}{c}\mathrm{N} \\
y \\
\mathrm{~N} \\
\mathrm{~N} \\
\text { Guo } \\
\text { dNTP }\end{array}$ & $k_{\text {cat }} / K_{\mathrm{m}}\left(\mu \mathrm{M}^{-1} \min ^{-1}\right)$ & $f$ & $\begin{array}{r}1, N 2 \\
\text { Template }\end{array}$ & ${ }_{N}^{N}$ & $k_{\text {cat }} / K_{\mathrm{m}}\left(\mu \mathrm{M}^{-1} \mathrm{~min}^{-1}\right)$ & $f$ \\
\hline \multirow[t]{3}{*}{ E. coli pol I KF (exo-) } & 3'-G*TA- & $N^{2}, 3-\varepsilon-d G: C$ & 0.23 & 1 & & $1, N^{2}-\varepsilon-d G: C$ & 0.0081 & 1 \\
\hline & & $N^{2}, 3-\varepsilon-\mathrm{dG}: \mathrm{T}$ & 0.24 & 1 & 3'-G*TG- & $1, N^{2}-\varepsilon-d G: G$ & 0.0087 & 1.1 \\
\hline & & & & & & $1, N^{2}-\varepsilon-d G: A$ & 0.0016 & 0.2 \\
\hline \multirow{2}{*}{$\begin{array}{l}\text { S. solfotaricus } \\
\text { Dpo4 }\end{array}$} & $3^{\prime}-G^{*} T A-$ & $N^{2}, 3-\varepsilon-\mathrm{dG}: \mathrm{C}$ & 0.025 & 1 & 3'-G*TA- & $1, N^{2}-\varepsilon-d G: C$ & 0.00006 & 1 \\
\hline & & $N^{2}, 3-\varepsilon-d G: T$ & 0.0054 & 0.22 & & $1, N^{2}-\varepsilon-d G: A$ & 0.0008 & 14 \\
\hline \multirow[t]{2}{*}{ Human pol $\mathrm{k}$} & $3^{\prime}-G^{*} T A-$ & $N^{2}, 3-\varepsilon-\mathrm{dG}: \mathrm{C}$ & 0.022 & 1 & 3'-G*TA- & $1, N^{2}-\varepsilon-d G: C$ & 0.0012 & 1 \\
\hline & & $N^{2}, 3-\varepsilon-d G: T$ & 0.0081 & 0.37 & & $1, N^{2}-\varepsilon-d G: T$ & 0.0012 & 1 \\
\hline \multirow[t]{2}{*}{ Human pol ı } & 3'-G*TA- & $N^{2}, 3-\varepsilon-d G: C$ & 0.0017 & 1 & $3^{\prime}-G^{*} T A-$ & $1, N^{2}-\varepsilon-d G: C$ & 0.0017 & 1 \\
\hline & & $N^{2}, 3-\varepsilon-d G: T$ & 0.0012 & 0.71 & & $1, N^{2}-\varepsilon-\mathrm{dG}: \mathrm{T}$ & 0.016 & 9.6 \\
\hline
\end{tabular}

$\mathrm{G}^{*}: N^{2}, 3-\varepsilon-\mathrm{dG}$ or $1, N^{2}-\varepsilon-\mathrm{dG} ; f=\left(k_{\text {cat }} / K_{\mathrm{m}}\right)_{\text {incorrect }} /\left(k_{\text {cat }} / K_{\mathrm{m}}\right)_{\text {correct }}$

Extension analysis pairings (LC-MS)

(Dpo4)

$$
\begin{aligned}
& N^{2}, 3-\varepsilon-\mathrm{dG}: \mathrm{C} \quad 45 \% \\
& N^{2}, 3-\varepsilon-\mathrm{dG}: \mathrm{T} \quad 35 \% \\
& N^{2}, 3-\varepsilon-\mathrm{dG}(-1) \sim 1 \%
\end{aligned}
$$

$1, N^{2}-\varepsilon-\mathrm{dG}: \mathrm{C} \quad<1 \%$

$1, N^{2}-\varepsilon-\mathrm{dG}: \mathrm{A} \quad 31 \%$

$1, N^{2}-\varepsilon-\mathrm{dG}(-1) 24 \%$ 


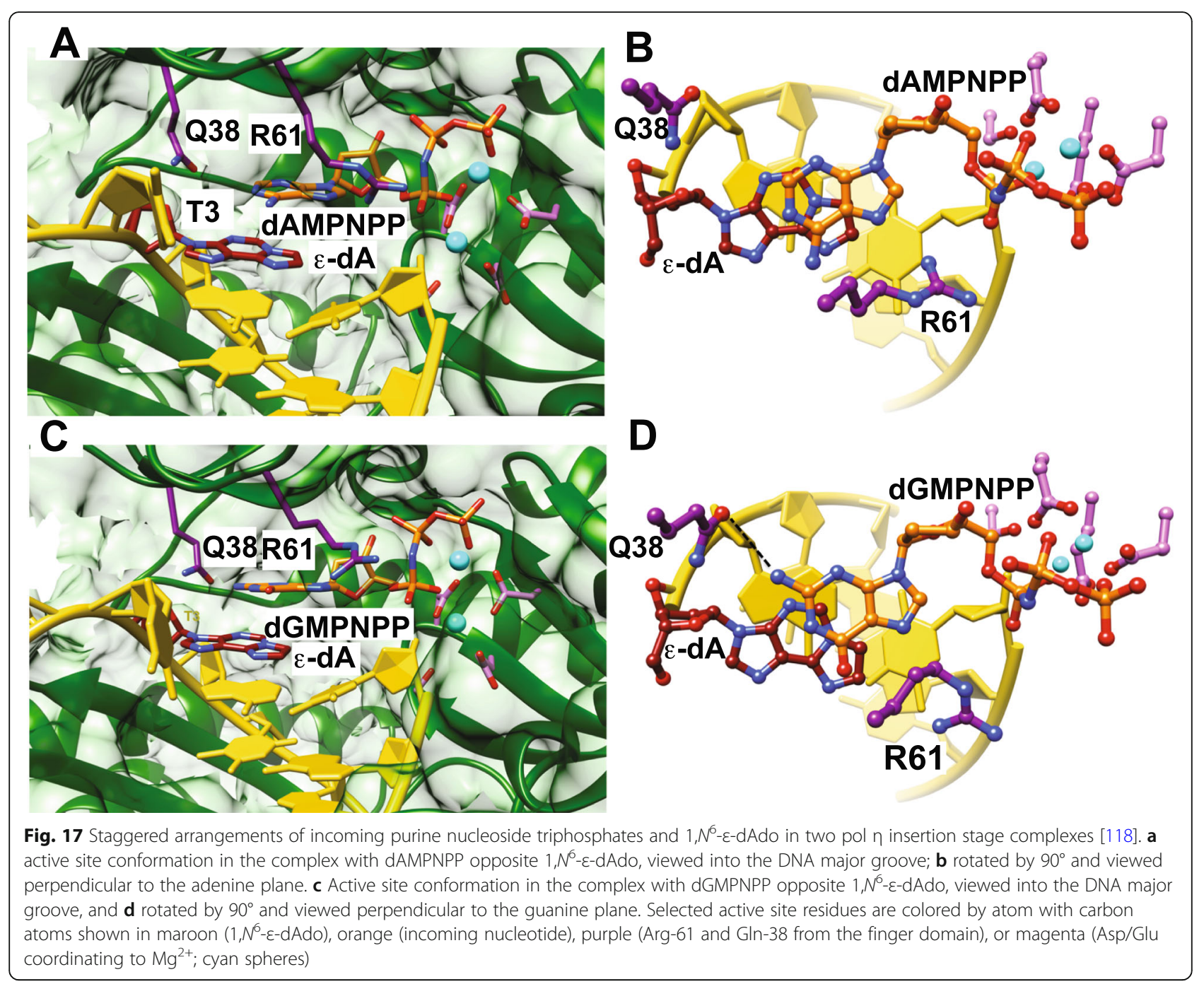

$N^{6}$ - $\varepsilon$-dAdo but were in a staggered configuration relative to $1, N^{6}-\varepsilon$-dAdo, opposite a 5 -dThd in the sequence and explaining the proclivity for frameshifts [118]. When a dTTP analog was positioned opposite $1, N^{6}-\varepsilon$-dAdo, the adduct was in the syn configuration. In a separate study, the Agarwal group [119] showed that pol ı used Hoogsteen base pairing to promote synthesis beyond $1, N^{6}-\varepsilon$ dAdo.

The $1, N^{2}-\varepsilon$-dGuo adduct completely blocks the normal Watson-Crick pairing face (Fig. 1) and has been studied extensively. Early studies with $E$. coli pol I and II, HIV reverse transcriptase, and rat pol $\beta$ showed normal incorporation and the insertion of dATP and dGTP [120]. In E. coli, all three mispaired bases were inserted ( $\mathrm{T}, \mathrm{A}$, G) [121]. Stable integration of an oligonucleotide in the chromosome of Chinese hamster ovary cells led to a number of base pair mutations (due mainly insertions of $\mathrm{A}$ and $\mathrm{T}$ opposite $1, N^{2}-\varepsilon$-Guo), plus substitutions removed from the site of DNA damage and some unexplained rearrangements [93].

A study with $1, N^{2}-\varepsilon$-dGuo and S. solfataricus Dpo4 yielded some initially confusing results, in that reaction of a primer:(1, $N^{2}-\varepsilon$-dGuo $)$ template complex led to the incorporation of three dATPs (Fig. 15), which seemed highly unusual in light of the sequence context, even if dATP were incorporated opposite $1, N^{2}$ - $\varepsilon$-dAdo. LC-MS approaches were developed to analyze the product, which proved to be a mixture of four major products. The content of each could be approximated by LC-MS (Fig. 16). A scheme could be drawn to explain the -1 and -2 frameshifts, plus the other products (Fig. 16). Xray structures (Fig. 18) of all oligonucleotide pairing possibilities shown in boxes (Fig. 16) could be solved [90]. A major structure is a "Type II" complex in which the polymerase skips the adduct and pairs with the next base [90]. Extension of the work to human DNA polymerases 
A
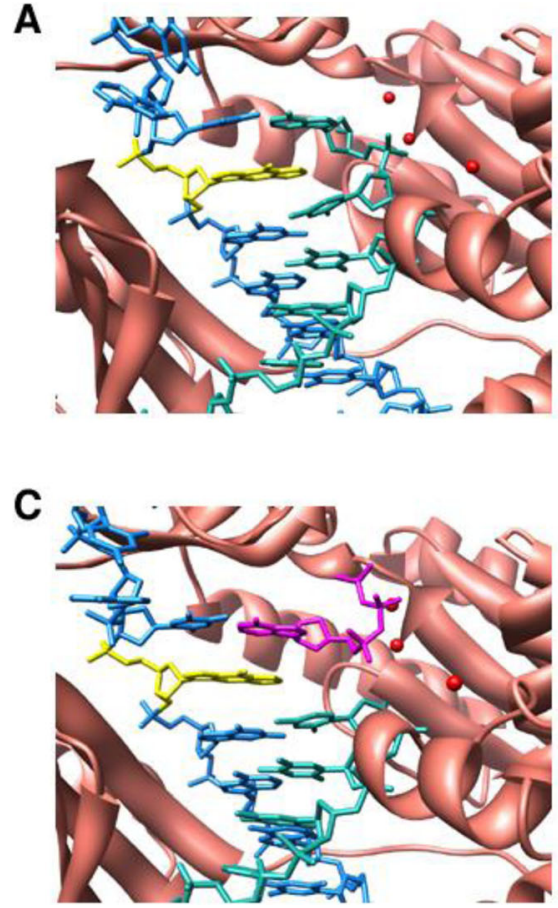

B

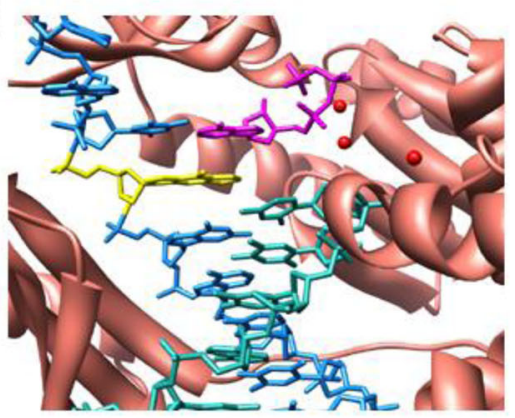

D

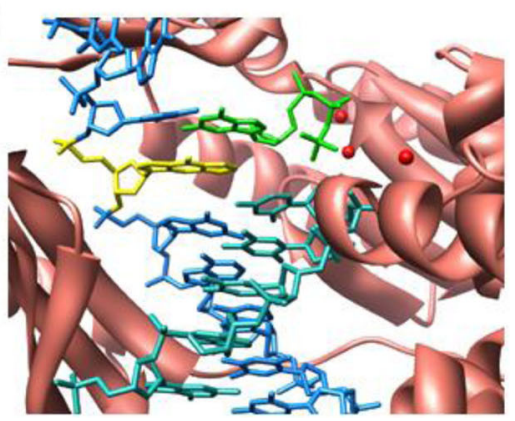

Fig. 18 Close views of active site regions of Dpo4 crystal structures [90]. a Dpo4·DNA $\cdot C^{2+}\left(X=1, N^{2}-\varepsilon-d G u o\right.$ and $\left.Z=T\right)$. b Dpo4 $\cdot D N A \cdot d A T P \cdot C a^{2+}$

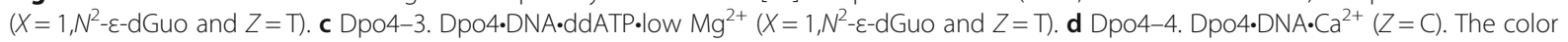
codes for protein and DNA are: dATP and ddATP are drawn in pink, ddGTP in green, and divalent metal ions are shown as red spheres

[105] showed that pol $\delta$ was completely blocked by the presence of $1, N^{2}-\varepsilon$-dGuo and that pol $\eta$ was the most active in copying past $1, N^{2}-\varepsilon$-dGuo. pol $\eta$ preferred to insert dGTP > dATP > dCTP. Apparently the $1, N^{2}-\varepsilon$ dGuo:dGuo base pairs are extended but others not so well. More recently, X-ray crystal structures have been obtained with $\mathrm{C}$ and A placed opposite $1, N^{2}$ - $\varepsilon$-dGuo in human pol $\eta$ [106]. Mass spectral analysis of fullyextended products revealed the misinertion of G (85\%) opposite $1, N^{2}$ - - -dGuo lesion. Importantly, the postlesion extension from the correct nucleotide pair $\left(1, N^{2}\right.$ $\varepsilon$-dGuo:dCyd) was not observed, indicating that the "correct" pair was retarded regarding extension past the lesion by pol $\eta[106]$.

Both 6- and 7-hydroxy derivatives of $1, N^{2}$-ethanodGuo (Fig. 2) are relevant biologically (Fig. 10) and have been examined for miscoding with some individual DNA polymerases $[2,120]$ and, in the case of 7-hydroxy derivative in $E$. coli cells [121]. The results are similar to those obtained with $1, N^{2}-\varepsilon$-dGuo, with some differences.

The miscoding potentials of two substituted $1, N^{2}-\varepsilon$ dGuo adducts derived from lipid peroxidation have also been examined. Moriya's group studied 3-(2-heptanone)-3, $N^{4}-\varepsilon$-dCyd and showed incorporation of dTTP and AATP in mouse fibroblasts [55]. The insertion of dTTP could be catalyzed by pol $\eta$, $\kappa$, or $~ \iota$ but insertion of dATP was attributed to a different, unknown polymerase, which could not extend beyond the insertion. Extension beyond the mispair was attributed to a pol $\xi$-Rev1 complex [55]. In a study with $S$. solfataricus Dpo4, the Rizzo laboratory found miscoding behavior of 7-(2-oxoheptyl)-1, $N^{2}-\varepsilon$-dGuo similar, but not identical, to $1, N^{2}-\varepsilon$-dGuo [57].

Although $N^{2}, 3-\varepsilon$-dGuo is more abundant in DNA than $1, N^{2}-\varepsilon$-dGuo (Table 1), it has been studied less. One of the major reasons is the technical difficulties in placing this lesion in an oligonucleotide because the glycosidic bond is unstable to hydrolysis [122]. Singer et al. [123, 124] were able to incorporate the nucleoside triphosphate into an oligonucleotide template and show misincorporation opposite the lesion with HIV-1 reverse transcriptase. Insertion of $1, N^{2}-\varepsilon-\mathrm{dGTP}$ opposite template $\mathrm{T}$ was also analyzed [124].

In order to circumvent the issue of the glycosidic instability of $N^{2}, 3-\varepsilon$-dGuo, we used an isostere approach previously applied to $N^{7}$-methylguanine [125]. Deoxyribose was replaced with 2 '-fluoroarabinose, i.e. the addition of fluorine at the $2^{\prime}$ carbon of the sugar ring adds electronegativity and destabilizes the transition state for glycosidic cleavage. The half-life of the adduct at $37^{\circ} \mathrm{C}$ was increased to 23 days and allowed detailed structural and biochemical studies to be done with both S. solfataricus Dpo4 and other enzymes, including human pol I [107, 108]. The overall differences in the 
behavior of $1, N^{2}-\varepsilon$-dGuo and $N^{2}, 3-\varepsilon$-dGuo are shown in Table 3. For $N^{2}, 3-\varepsilon$-dGuo the fidelity (with Dpo4) is considerably higher and there are few frameshifts. With Dpo4, the crystal structure of the $1, N^{2}-\varepsilon$-dGuo:dCTP pair is pseudo-Watson Crick and the $1, N^{2}-\varepsilon$-dGuo:dTTP pairing is "wobble-like" (Fig. 18) [107]. With pol ı, there was Hoogsteen-like pairing, with two hydrogen bonds in the $N^{2}, 3-\varepsilon$-dGuo:dCTP pair and only one in the $N^{2}, 3-\varepsilon$ dGuo:dTTP pair (Fig. 19) [108]. dTTP insertion was the major misincorporation event with all of the human YFamily TLS polymerases examined, with pol ı having the highest frequency [108].

The dTTP pairing with $N^{2}, 3-\varepsilon$-dGuo is also consistent with a dominant $\mathrm{G}$ to A transition pattern seen with $N^{2}$, 3-E-dGuo in E. coli [99]. Collectively, the work is relevant in that $G$ to $A$ transitions were the dominant mutations observed in vinyl chloride-associated liver tumors [126]. Perhaps the mystery of vinyl chloride and cancer etiology has finally been revealed.

\section{Repair of etheno DNA adducts}

The repair of etheno adducts has long been studied, going back $>30$ years. Swenberg et al. [127] reported that $1, N^{6}-\varepsilon$-dAdo, $3, N^{4}-\varepsilon$-dCyd, and $N^{2}, 3-\varepsilon$-dGuo were all persistent in rat liver. Moreover, the ratios of the adducts (Table 2) differ from what is observed upon reaction of 2-chloroethylene oxide with DNA (Table 1), suggesting different half-lives of individual adducts.

Oesch et al. [128] reported the release of $1, N^{6}-\varepsilon$-dAdo and $N^{2}, 3-\varepsilon$-dGuo from chloroacetaldehyde-treated DNA by an extract of rat brain cells. Rydberg et al. [129, 130] reported glycosylase activity towards $1, N^{6}-\varepsilon$-dAdo in human cell-free extracts, and Singer et al. [131] reported that human $N^{3}$-methyl Ade-DNA glycosylase could act on $1, N^{6}-\varepsilon$-dAdo. Although Singer's group reported that a single human DNA glycosylase could release $1, N^{6}-\varepsilon$ dAdo, 3,N $N^{4}-\varepsilon$-dCyd, $1, N^{2}-\varepsilon$-dGuo, and $N^{2}, 3-\varepsilon$-dGuo [132], they subsequently reported that $1, N^{6}-\varepsilon$-dAdo and $3, N^{4}-\varepsilon$-dCyd were excised by separate (human) glycosylases [133]. Later, Saparvaev et al. [134] reported that $E$. coli mismatch-specific uracil-DNA glycosylase and human alkylpurine-DNA-N-glycosylase can excise $1, N^{2}-\varepsilon$ dGuo. Ethano Cyt and Ade adducts (saturated) are also substrates for E. coli glycosylases [135].

Repair of DNA etheno adducts is not restricted to glycosylases, in that they are also subject to direct reversal and nucleotide excision repair (NER) (Fig. 20). Evidence has also been reported that NER can be involved in DNA repair, at least for $1, N^{6}-\varepsilon$-dAdo and $3, N^{4}-\varepsilon-\mathrm{dCyd}$ (Fig. 20) [136, 137].

AlkB is an $\alpha$-ketoglutarate-dependent dioxygenase that was discovered in bacteria for its ability to catalyze
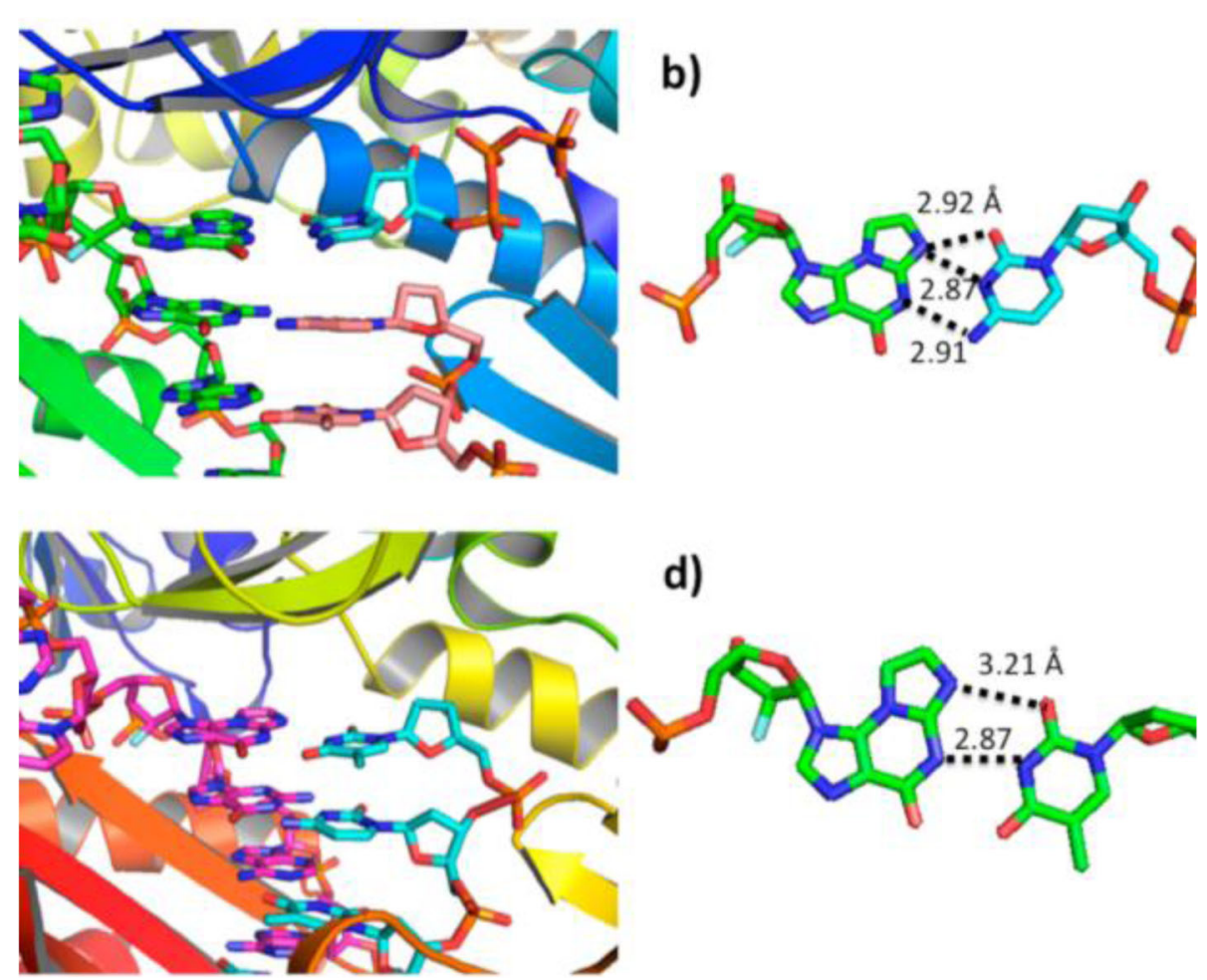

Fig. 19 Crystal structures of Dpo4• $N^{2}, 3-\varepsilon-d G u o-D N A$ complex ( $Z=C$ in the template) [107]. a Ternary complex of dCTP• $N^{2}, 3-\varepsilon-d G u o$ and $\mathbf{b}$ the orientation of the bases with proposed hydrogen bonding mechanism. $\mathbf{c}$ Binary complex of ddT• $N^{2}, 3-\varepsilon-d G u o$ and $\mathbf{d}$ the orientation of the bases with proposed hydrogen bonding mechanism 


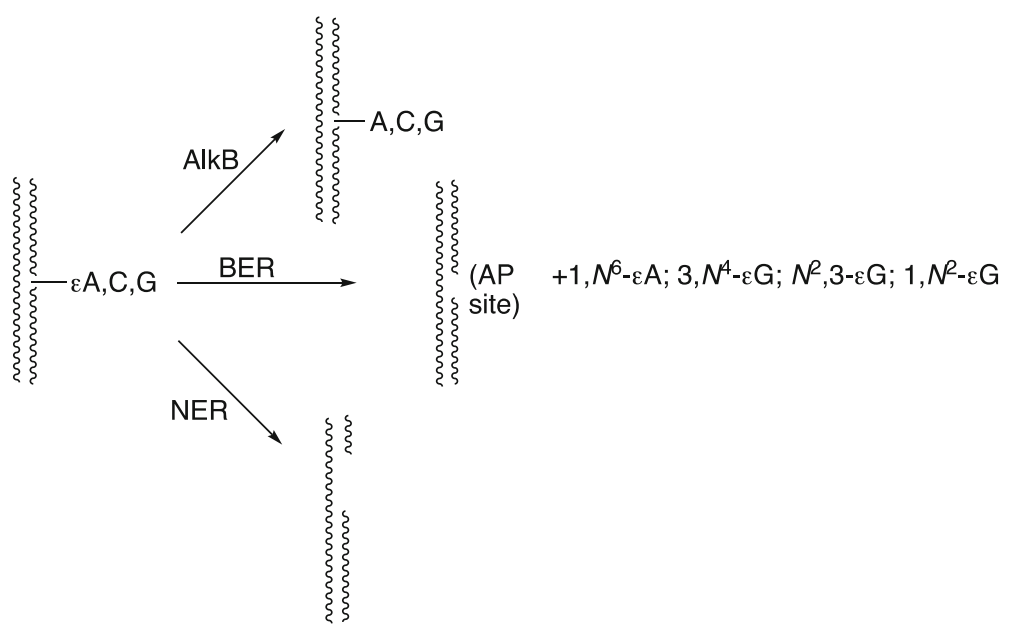

Fig. 20 Mechanisms of repair of etheno DNA adducts. AlkB is a direct pathway catalyzed the bacterial dioxygenase AlkB and mammalian homologues. BER: base excision repair. NER: nucleotide excision repair

hydroxylation and removal of alkyl groups at the ring nitrogens of DNA bases. The Essigmann laboratory showed that the enzyme, and its mammalian orthologues, can catalyze the direct removal of the two carbons of etheno bases $\left(1, N^{6}\right.$ - $\varepsilon$-dAdo; $3, N^{4}-\varepsilon$-dCyd) as glyoxal (Fig. 21). Tudek and associates compared the removal of $1, N^{6}$ - $\varepsilon$-dAdo, $3, N^{4}-\varepsilon$-dCyd, and $1, N^{2}-\varepsilon$-dGuo by nine bacterial AlkB and two human AlkB homologues [139]. Two bacterial AlkB-type enzymes had no activity. Three removed all three of the etheno adducts, and two of these did not act on any alkyl DNA adducts. Another three removed $1, N^{6}-\varepsilon$-dAdo and $3, N^{4}-\varepsilon$-Cyd but not 1 , $N^{2}-\varepsilon$-dGuo. The human AlkB orthologues varied in their activities [139].

An interesting reaction occurs with $1, N^{2}-\varepsilon$-Gua and 7(2-heptanone)-1, $N^{2}-\varepsilon$-Gua, in which the 2 -carbon is oxygenated by xanthine oxidoreductase (Fig. 22) [140]. No

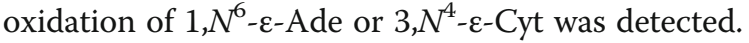

\section{Copying of $1, N^{6}-\varepsilon$-ado in DNA as well as in RNA}

The incorporation of ribonucleotides during DNA replication represents a threat to the genome and its stability [141-143]. In particular, a ribo backbone may increase the risk of spontaneous hydrolysis that can lead to DNA strand breaks [144, 145], although this conclusion is controversial [146]. Embedded ribonucleotides have also been linked with systemic autoimmunity and chromosomal instability [147]. The main reasons for rNTP insertions are the higher cellular concentrations of rNTPs (over dNTPs), lack of complete sugar discrimination, and persistence of a ribo-backbone in DNA due to the incomplete removal RNA stretches from Okazaki fragments [148-151]. The human RNase H2-mediated ribonucleotide excision repair (RER) pathway helps in stabilizing genomic integrity by removing embedded ribonucleotides from DNA [152-154].

However, some ribonucleotides in DNA may persist [155], and these embedded ribonucleotides are considered a type of DNA damage. It is very important to understand the fate of ribonucleotides that escape repair. The TLS DNA damage tolerance pathway can have an important role in this context. Pol $\eta$ can bypass the embedded ribonucleotides in DNA, and our own studies have shown novel functions of pol $\eta$ [156-159]. However, little is known about pol $\eta$-mediated TLS across from a ribonucleotide in the DNA, and it is important to

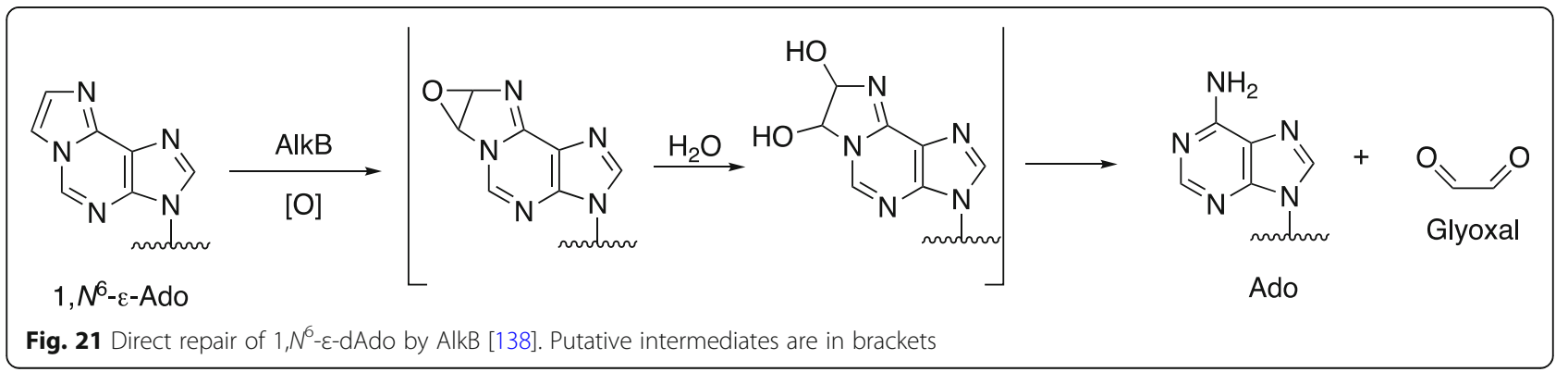


<smiles>[R]O[C](C)c1c[nH]c2nc3[nH]c(=O)[nH]c3c(=O)n12</smiles><smiles></smiles>

Fig. 22 Oxidation of $1, N^{2}-\varepsilon$-Gua and heptanone-1, $N^{2}-\varepsilon$-Gua by xanthine oxidoreductase (XOR) [140]

know the role of pol $\eta$ in the context of ribonucleotides, either in the form of an RNA template or as ribonucleotides in DNA.

Our studies revealed interesting details about ribonucleotide tolerance, reverse transcription, and RNA primer extension events for the most abundant nucleotide, Ado, and its modified analog $1, N^{6}-\varepsilon$-Ado [159]. In pol $\eta$ mediated bypass studies using physiological concentrations of dNTPs, as well as rNTPs (Fig. 23), a DNA primer was fully extended using dNTPs when hybridized with an Ado-containing DNA template (DNA-Ado, Fig. 23A, lanes 1-4), but less processive extension was observed for rNTPs (Fig. 23A, lanes 5-8), pol $\eta$ mediated TLS was slower opposite $1, N^{6}-\varepsilon$-Ado as compared to Ado in a DNA template. The bypass of $1, N^{6}-\varepsilon-$ Ado was inefficient using dNTPs (Fig. 23B, lanes 1-4), and with rNTPs the reactions were completely retarded (Fig. 23B, lanes 5-8). The TLS process was attenuated in the presence of $1, N^{6}-\varepsilon$-Ado (Fig. 23A, B, compare lane
1 ), and hpol $\eta$ performed error-prone bypass of $1, N^{6}-\varepsilon$ Ado. Single nucleotide insertion and steady-state kinetic studies indicated that pol $\eta$ preferably inserted dATP and dGTP opposite a $1, N^{6}$ - - -Ado-modified DNA template (compared to dTTP and dCTP). No rNTP incorporation was observed opposite $1, N^{6}$ - -Ado in DNA, indicating that pol $\eta$ follows a purine rule due to preference for adding deoxyribopurines (over ribo-purines) opposite $1, N^{6}-\varepsilon$-Ado. In steady-state kinetic analyses, dTTP insertion opposite $1, N^{6}-\varepsilon$-Ado was very unfavorable compared to other dNTPs [159].

Mass spectral analysis of pol $\eta$-mediated TLS products of the DNA/DNA-1, $N^{6}$ - - -Ado complex revealed frameshifts (one deletion) opposite the lesion, using physiological concentrations of dNTPs. Thus, $1, N^{6}-\varepsilon$-Ado can exist in a staggered configuration and the polymerase may skip the lesion, and pairing of an incoming nucleotide with the next neighboring base on the template can be favored [118]. In addition to frameshifts, products with the

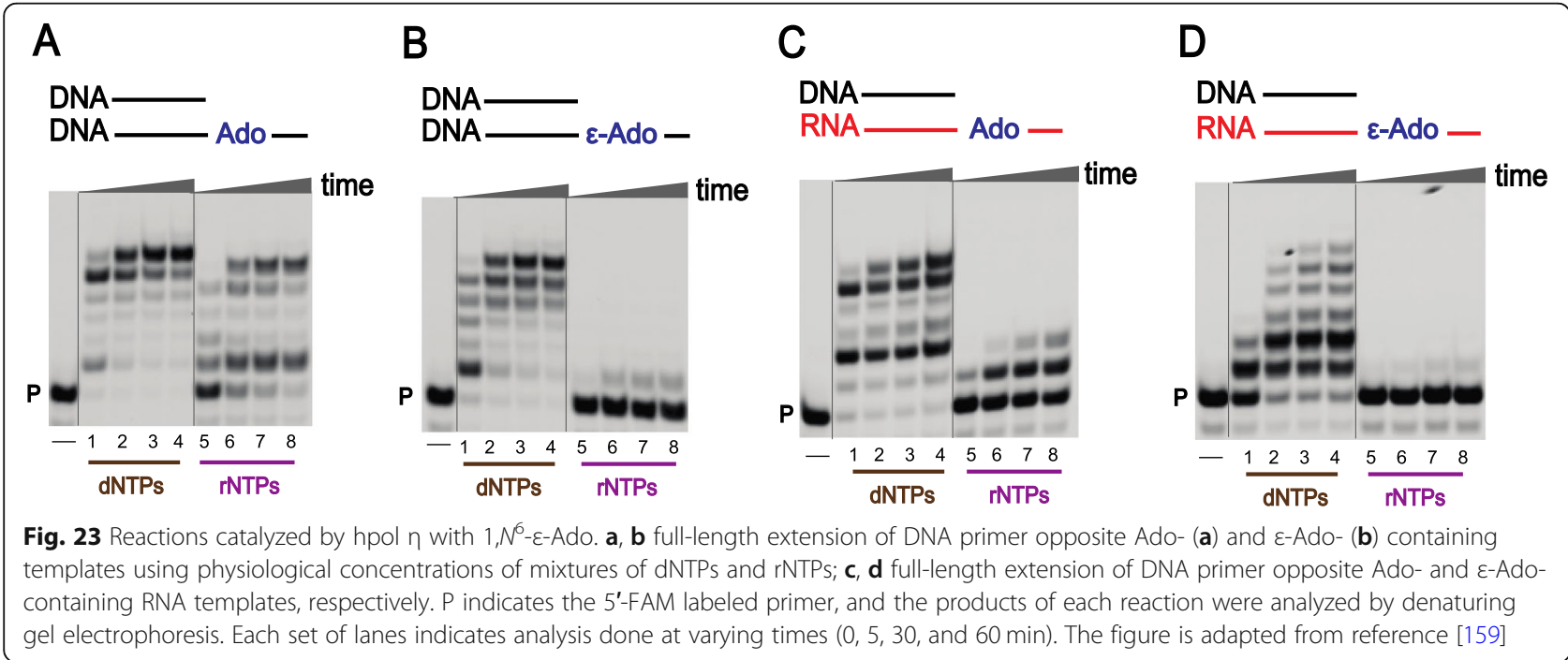


insertion of A and G opposite $1, N^{6}-\varepsilon$-Ado lesion were also observed [159]. In addition, mis-insertion of $\mathrm{G}$ in the extension step was also observed [159]. Overall, steady-state kinetic and mass spectral analyses both showed the insertion of A and G opposite $1, N^{6}$ - - -Ado while mass spectral analysis revealed frameshift products opposite the lesion.

pol $\eta$-mediated reverse transcription activities were also analyzed using Ado- and $1, N^{6}$ - - -Ado-containing RNA templates (Fig. 23C-D), utilizing physiological concentrations of dNTPs as well as rNTPs. Across from the lesion, the DNA primer was extended with low processivity using a mixture of dNTPs (Fig. 23D, lanes 1-4), but extension reactions were strongly retarded with rNTPs (Fig. 23D, lanes 5-8). Thus, pol $\eta$ acted as a reverse transcriptase and added only dNTPs (instead of rNTPs) opposite $1, N^{6}-\varepsilon$-Ado. The single nucleotide insertion assays showed that, for a $1, N^{6}-\varepsilon$-Ado-modified template, pol $\eta$ preferably added dATP and dGTP, a similar base selectivity as observed in the TLS process. Steady-state kinetic analysis indicated that the incorporation of dTTP across $1, N^{6}-\varepsilon$-Ado was quite unfavorable, as observed in the TLS process. Overall, pol $\eta$ catalyzed faithful reverse transcription opposite a $1, N^{6}-\varepsilon$-Ado-containing RNA template because of the preference for dNTPs over rNTPs [159].
RNA primer extension opposite the $1, N^{6}$ - $\varepsilon$-Ado-containing DNA template showed that pol $\eta$-mediated RNA primer extension was severely disturbed as compared with an Ado-containing DNA template (using dNTPs). Overall, pol $\eta$ follows a purine rule, with preference for dGTP insertion opposite $1, N^{6}-\varepsilon$-Ado imbedded in DNA. No rNTP incorporation was observed opposite $1, N^{6}-\varepsilon$ Ado with an RNA primer [159].

\section{Human RNase H2-mediated incision of $1, N^{6}$ - $\varepsilon$-ado in DNA}

The endoribonuclease activity of human RNase $\mathrm{H} 2$ opposite dAdo, Ado, and $1, N^{6}-\varepsilon$-Ado in the DNA template was examined (with the complementary base $\mathrm{T}$ ). Incision assays showed that RNase $\mathrm{H} 2$-mediated recognition and incision of Ado in DNA-Ado template was very efficient (Fig. 24, lanes 7-12), but the endoribonuclease activity was significantly reduced when a DNA duplex was used containing a $1, N^{6}-\varepsilon$-Ado modification (Fig. 24, lanes 1318). These results indicate that RNase $\mathrm{H} 2$ is able to recognize the damaged ribonucleotide $1, N^{6}-\varepsilon$-Ado but exhibits only partial incision activity. Importantly, the human RNase $\mathrm{H} 2$-mediated recognition and repair of Ado and $1, N^{6}-\varepsilon$-Ado was entirely different, apparently due to the presence of the etheno group on the

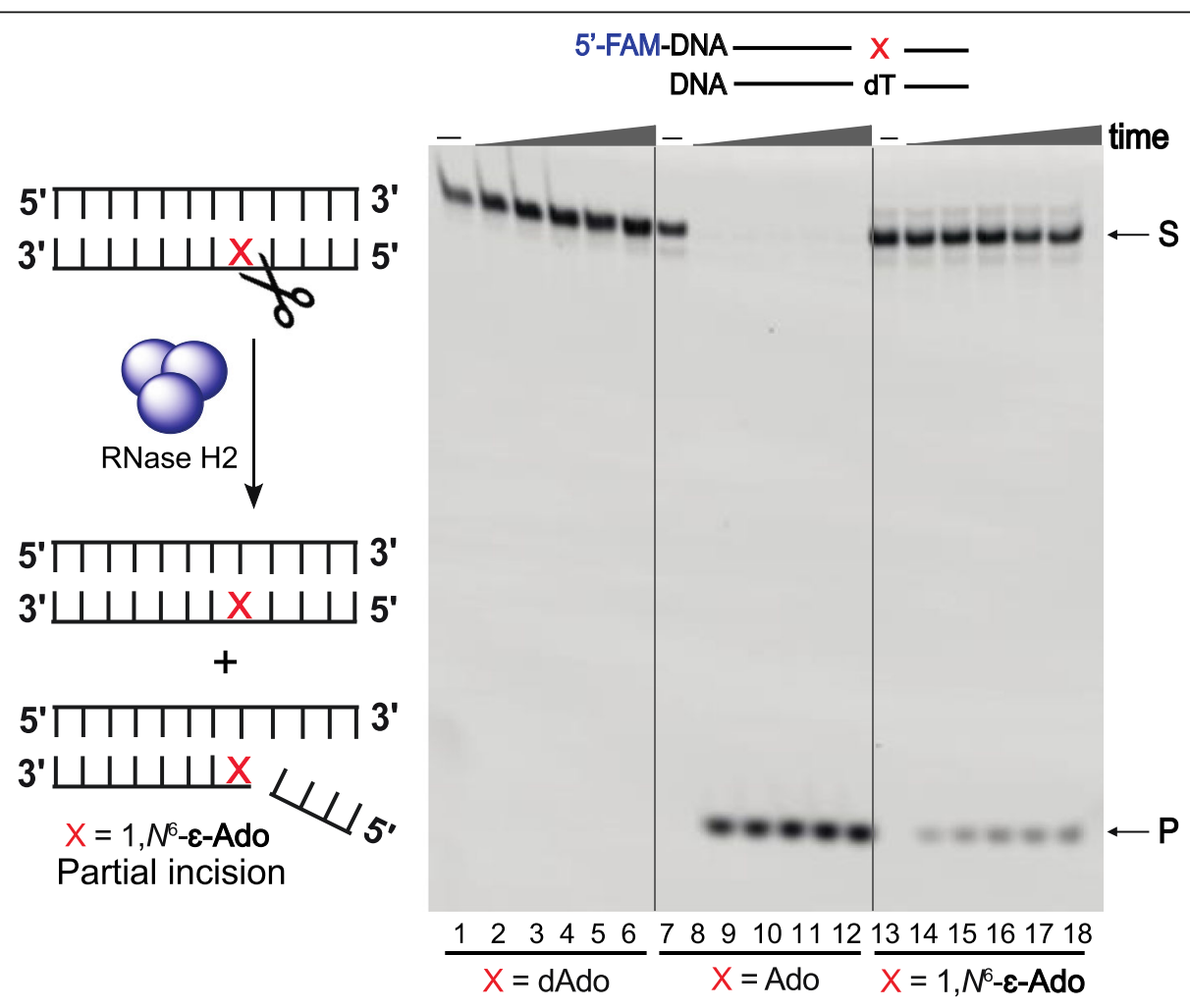

Fig. 24 Repair of $1, N^{6}-\varepsilon-A d o-c o n t a i n i n g ~ D N A$ by RNase H2. Incision assays for DNA-X/DNA-dT employing human RNase H2. S denotes the 5'-FAM labeled substrate, and P denotes the incised product. The products of each reaction were analyzed by denaturing gel electrophoresis. Each set of lanes indicates analysis done at varying times $(0,5,15,30,45$, and $60 \mathrm{~min})$. The figure is adapted from reference [159] 
adenosine. If this adduct persists in the DNA and TLS is the only way of coping with $1, N^{6}-\varepsilon$-Ado, then the versatile human TLS pol $\eta$ may tolerate this adduct but in an error prone way. In addition, the possibility of a base excision repair pathway in removing this adduct from DNA cannot be excluded.

\section{Conclusions}

The etheno story is one in which chemical and biological curiosity came to have considerable relevance in biomedical applications. The story began with determination of the structures of some unusual tRNA entities, the Y-bases. The chemistry led to some useful fluorescent reagents and served as a basis for synthesis and understanding the mechanism of how these bases are formed following exposure to both exogenous and endogenous sources of bis-electrophiles, e.g. vinyl monomers. Relevance to the highly unusual cancers (hemangiosarcomas) related to industrial exposure to vinyl chloride was a key event, and today the most documented basis for the tumors may be the $N^{2}, 3-\mathrm{dGuo}$ : dTTP pairing ( $G$ to A transitions) $[99,126]$. Considerable insight has been gained in the formation and repair of DNA etheno adducts. The discovery of the etheno adducts in DNA and RNA of experimental animals and humans never exposed to vinyl monomers and other prospective bis-electrophiles in the environment led to the discovery of the role of lipid peroxidation, and the adducts may be related to the association of cancer with different diets and lifestyles. Finally, the story has come full circle, in a sense, with the discovery that RNA etheno adducts can be copied and lead to mistakes in DNA [159].

\section{Abbreviations \\ Ade: Adenine; Cyt: Cytosine; Gua: Guanine; Ado: Adenosine; Cyd: Cytidine; Guo: Guanosine; dAdo: deoxyadenosine; dCyd: deoxycytidine; dGuo: deoxyguanosine; dThd: deoxythymidine: $1, N^{6}-\varepsilon$-Ado: $1, N^{6}-$ ethenoadenosine; $3, N^{4}-\varepsilon$-Cyd: $3, N^{4}$-ethenocytidine; $1, N^{2}-\varepsilon$-Gua: $1, N^{2}-$ ethenoguanine; $1, N^{2}-\varepsilon$-Guo: $1, N^{2}$-ethenoguanosine; $N^{2} 3-\varepsilon$-Guo: $1, N^{2}$ - ethenoguanosine; $1, N^{6}-\varepsilon$-dAdo: $1, N^{6}$-ethenodeoxyadenosine; $3, N^{4}-\varepsilon$ - dCyd: $3, N^{4}$-ethenodeoxycytidine; $1, N^{2}-\varepsilon$-dGuo: $1, N^{2}$-ethenodeoxyguanosine; $N^{2}, 3-\varepsilon$-dGuo: 1, $N^{2}$-ethenodeoxyguanosine; FAM: 6-carboxyfluorescein; P450: cytochrome P450; pol: DNA polymerase; NER: Nucleotide excision repair; RER: Ribonucleotide excision repair; TLS: Translesion synthesis}

\section{Acknowledgements}

We thank K. Trisler for assistance in preparation of the manuscript. This review is dedicated to the memory of Professor Takashi Sugimura, a longtime pioneer in the study of environmental mutagens, who one of us (F.P. G.) had the privilege to know personally.

\section{Authors' contributions}

Both authors wrote the paper. The author(s) read and approved the final manuscript.

\section{Funding}

Research related to this article was supported by U. S. National Institute of Health grants R01 ES010546 and R01 ES026955. The content is solely the responsibility of the authors and does not necessarily represent the official views of the National Institutes of Health.
Availability of data and materials

Not applicable.

\section{Declarations}

Ethics approval and consent to participate N/A

Consent for publication

Not applicable.

\section{Competing interests}

The authors declare that they have no competing interests.

Received: 8 March 2021 Accepted: 3 June 2021

Published online: 16 June 2021

\section{References}

1. Guengerich FP, Persmark M, Humphreys WG. Formation of $1, N^{2}$ - and $N^{2}, 3-$ ethenoguanine from 2-halooxiranes: isotopic labeling studies and isolation of a hemiaminal derivative of $\mathrm{N}^{2}$-(2-oxoethyl)guanine. Chem Res Toxicol. 1993;6(5):635-48. https://doi.org/10.1021/tx00035a008.

2. Goodenough AK, Kozekov ID, Zang H, Choi J-Y, Guengerich FP, Harris TM, et al. Site specific synthesis and polymerase bypass of oligonucleotides containing a 6-hydroxy-3,5,6,7-tetrahydro-9H-imidazo[1,2-a]purin-9-one base, an intermediate in the formation of $1, N^{2}$-etheno-2'-deoxyguanosine. Chem Res Toxicol. 2005;18(11):1701-14. https://doi.org/10.1021/tx050141k.

3. Hecht SS, Young-Sciame R, Chung FL. Reaction of a-acetoxy-Nnitrosopiperidine with deoxyguanosine: oxygen-dependent formation of 4oxo-2-pentenal and a 1, $N^{2}$-ethenodeoxyguanosine adduct. Chem Res Toxicol. 1992;5:706-12.

4. Blair IA. DNA adducts with lipid peroxidation products. J Biol Chem. 2008; 283(23):15545-9.

5. Rajbhandary UL, Chang SH, Stuart A, Faulkner RD, Hoskinson RM, Khorana HG. Studies on polynucleotides, LXVIII. The primary structure of yeast phenylalanine transfer RNA. Proc Natl Acad Sci U S A. 1967;57(3):751-8. https://doi.org/10.1073/pnas.57.3.751.

6. Yoshikami D, Katz G, Keller EB, Dudock BS. A fluorescence assay for phenylalanine transfer RNA. Biochim Biophys Acta. 1968;166(3):714-7. https://doi.org/10.1016/0005-2787(68)90382-1.

7. Thiebe R, Zachau HG. A specific modification next to the anticodon of phenylalanine transfer ribonucleic acid. Eur J Biochem. 1968;5(4):546-55. https://doi.org/10.1111/j.1432-1033.1968.tb00404.x.

8. Blobstein SH, Grunberger D, Weinstein IB, Nakanishi K. Isolation and structure determination of the fluorescent base from bovine liver phenylalanine transfer ribonucleic acid. Biochemistry. 1973;12(0006-2960 (print)):188-93.

9. Blobstein SH, Gebert R, Grunberger D, Nakanishi K, Weinstein IB. Structure of the fluorescent nucleoside of yeast phenylalanine transfer ribonucleic acid. Arch Biochem Biophys. 1975;167(2):668-73. https://doi.org/10.1016/00039861(75)90510-x.

10. Kasai H, Goto M, Ikeda K, Zama M, Mizuno Y, Takemura S, et al. Structure of wye (Yt base) and wyosine (Yt) from Torulopsis utilis phenylalanine transfer ribonucleic acid. Biochemistry. 1976;15(4):898-904. https://doi.org/10.1021/ bi00649a027.

11. McCloskey JA, Crain PF, Edmonds CG, Gupta R, Hashizume T, Phillipson DW, et al. Structure determination of a new fluorescent tricyclic nucleoside from archaebacterial tRNA. Nucleic Acids Res. 1987;15(2):683-93. https://doi.org/1 $0.1093 /$ nar/15.2.683

12. de Crécy-Lagard V, Brochier-Armanet C, Urbonavičius J, Fernandez B, Phillips $G$, Lyons $B$, et al. Biosynthesis of wyosine derivatives in tRNA: an ancient and highly diverse pathway in archaea. Mol Biol Evol. 2010;27(9):2062-77. https://doi.org/10.1093/molbev/msq096.

13. Noma A, Kirino Y, Ikeuchi Y, Suzuki T. Biosynthesis of wybutosine, a hypermodified nucleoside in eukaryotic phenylalanine tRNA. EMBO J. 2006;25(10): 2142-54. https://doi.org/10.1038/sj.emboj.7601105.

14. Young AP, Bandarian V. Pyruvate is the source of the two carbons that are required for formation of the imidazoline ring of 4-demethylwyosine. Biochemistry. 2011;50(49):10573-5. https://doi.org/10.1021/bi2015053.

15. Perche-Letuvée P, Kathirvelu V, Berggren G, Clemancey M, Latour J-M, Maurel V, et al. 4-Demethylwyosine synthase from Pyrococcus abyssi ith the 
pyruvate co-substrate. J Biol Chem. 2012;287(49):41174-85. https://doi.org/1 0.1074/jbc.M112.405019.

16. Guengerich FP, Yoshimoto FK. Formation and cleavage of $\mathrm{C}-\mathrm{C}$ bonds by enzymatic oxidation-reduction reactions. Chem Rev. 2018;118(14):6573-655. https://doi.org/10.1021/acs.chemrev.8b00031.

17. Kochetkov NK, Shibaev VN, Kost AA. New reaction of adenine and cytosine derivatives, potentially useful for nucleic acids modification. Tetrahedron Lett. 1971;22:1993-6.

18. Barrio JR, Secrist JA III, Leonard NJ. Fluorescent adenosine and cytidine derivatives. Biochem Biophys Res Commun. 1972;46(2):597-604. https://doi. org/10.1016/S0006-291X(72)80181-5.

19. Secrist JAI, Barrio JR, Leonard NJ, Weber G. Fluorescent modification of adenosine-containing coenzymes. Biol Activities Spectroscopic Properties Biochem. 1972;11:3499-506.

20. Barrio JR, Secrist JA 3rd, Leonard NJ. A fluorescent analog of nicotinamide adenine dinucleotide. Proc Natl Acad Sci U S A. 1972;69(8):2039-42. https:// doi.org/10.1073/pnas.69.8.2039.

21. Secrist JA 3rd, Barrio JR, Leonard NJ. A fluorescent modification of adenosine triphosphate with activity in enzyme systems: $1, N^{6}$ ethenoadenosine triphosphate. Science. 1972;175(4022):646-7. https://doi. org/10.1126/science.175.4022.646

22. Secrist JA 3rd, Barrio JR, Leonard NJ, Villar-Palasi C, Gilman AG. Fluorescent modification of adenosine $3^{\prime}, 5^{\prime}$-monophosphate: spectroscopic properties and activity in enzyme systems. Science. 1972;177(4045):279-80. https://doi. org/10.1126/science.177.4045.279.

23. Digweed M, Erdmann VA, Odom OW, Hardesty B. Fluorescence modification of Escherichia coli 5S RNA. Nucleic Acids Res. 1981;9(13):3187-98. https://doi. org/10.1093/nar/9.13.3187.

24. Creech JL Jr, Johnson MN. Angiosarcoma of liver in the manufacture of polyvinyl chloride. J Occup Med. 1974;16(3):150-1.

25. Vinyl chloride. IARC Monographs. Int Agency Res Cancer, Lyon. 1974;7: 291-310.

26. Malaveille C, Bartsch H, Barbin A, Camus AM, Montesano R. Mutagenicity of vinyl chloride, chloroethylene oxide, chloroacetaldehyde and chloroethanol. Biochem Biophys Res Commun. 1975;63(2):363-70. https://doi.org/10.1016/ 0006-291X(75)90697-X.

27. Barbin $A$, Brésil $H$, Croisy $A$, Jacquignon $P$, Malaveille $C$, Montesano $R$, et al. Liver-microsome-mediated formation of alkylating agents from vinyl bromide and vinyl chloride. Biochem Biophys Res Commun. 1975;67(2):596603. https://doi.org/10.1016/0006-291X(75)90854-2

28. Laib RJ, Bolt HM. Alkylation of RNA by vinyl chloride metabolites in vitro and in vivo: formation of 1,N6-ethenoadenosine. Toxicology. 1977:8:185-95.

29. Laib RJ, Gwinner LM, Bolt HM. DNA alkylation by vinyl chloride metabolites: etheno derivatives or 7-alkylation of guanine? Chem Biol Interact. 1981;37(12):219-31. https://doi.org/10.1016/0009-2797(81)90179-4.

30. Bergman K. Reactions of vinyl chloride with RNA and DNA of various mouse tissues in vivo. Arch Toxicol. 1982;49(2):117-29. https://doi.org/10.1007/ BF00332359.

31. Sattsangi PD, Leonard NJ, Frihart CR. $1, N^{2}$-Ethenoguanine and $N^{2}, 3-$ ethenoguanine. Synthesis and comparison of the electronic spectral properties of these linear and angular triheterocycles related to the $Y$ bases. J Organomet Chem. 1977:42:3292-6.

32. Kusmierik JT, Singer B. 1, $N^{2}$-Ethenodeoxyguanosine: properties and formation in chloroacetaldehyde-treated polynucleotides and DNA. Chem Res Toxicol. 1992;5(5):634-8. https://doi.org/10.1021/tx00029a007.

33. Guengerich FP, Mason PS, Stott WT, Fox TR, Watanabe PG. Roles of 2haloethylene oxides and 2-haloacetaldehydes derived from vinyl bromide and vinyl chloride in irreversible binding to protein and DNA. Cancer Res. 1981:41(11 Pt 1):4391-8.

34. Guengerich FP. Roles of the vinyl chloride oxidation products 1chlorooxirane and 2-chloroacetaldehyde in the in vitro formation of etheno adducts of nucleic acid bases. Chem Res Toxicol. 1992;5(1):2-5.

35. Müller M, Belas FJ, Blair IA, Guengerich FP. Analysis of $1, N^{2}$-ethenoguanine and 5,6,7,9-tetrahydro-7-hydroxy-9-oxoimidazo[1,2-a] purine in DNA treated with 2-chlorooxirane by high performance liquid chromatography/ electrospray mass spectrometry and comparison of amounts to other DNA adducts. Chem Res Toxicol. 1997;10(2):242-7. https://doi.org/10.1021/ tx960124i

36. Gwinner LM, Laib RJ, Filser JG, Bolt HM. Evidence of chloroethylene oxide being the reactive metabolite of vinyl chloride towards DNA: comparative studies with 2,2'-dichlorodiethylether. Carcinogenesis. 1983;4(11):1483-6. https://doi.org/10.1093/carcin/4.11.1483.

37. Okazaki O, Persmark M, Guengerich FP. N-Nitroso-N-methylvinylamine: reaction of the epoxide with guanyl and adenyl moieties to yield adducts derived from both parts of the molecule. Chem Res Toxicol. 1993;6(2):16873. https://doi.org/10.1021/tx00032a005.

38. Guengerich FP, Raney VM. Formation of etheno adducts of adenosine and cytidine from 1-halooxiranes. Evidence for a mechanism involving initial reaction with the endocyclic nitrogens. J Am Chem Soc. 1992;114:1074-80.

39. Ribovich ML, Miller JA, Miller EC, Timmins LG. Labeled $1, N^{6}$ ethenoadenosine and 3,N-2thenocytidine in hepatic RNA of mice given [ethyl-1,2- $-{ }^{3} \mathrm{H}$ or ethyl-1-14 $\mathrm{C}$ ] ethyl carbamate (urethan). Carcinogenesis. 1982; 3:539-46.

40. Dahl GA, Miller JA, Miller EC. Vinyl carbamate as a promutagen and a more carcinogenic analog of ethyl carbamate. Cancer Res. 1978;38:3793-804.

41. Guengerich FP, Kim D-H. Enzymatic oxidation of ethyl carbamate to vinyl carbamate and its role as an intermediate in the formation of $1, N^{6}$ ethenoadenosine. Chem Res Toxicol. 1991;4(4):413-21. https://doi.org/10.1 021/tx00022a003.

42. Guengerich FP, Geiger LE, Hogy LL, Wright PL. In vitro metabolism of acrylonitrile to 2-cyanoethylene oxide, reaction with glutathione, and irreversible binding to proteins and nucleic acids. Cancer Res. 1981;41(12 Pt 1):4925-33.

43. Guengerich FP, Kim DH, Iwasaki M. Role of human cytochrome P-450 IIE1 in the oxidation of many low molecular weight cancer suspects. Chem Res Toxicol. 1991;4(2):168-79. https://doi.org/10.1021/tx00020a008.

44. Fedtke N, Boucheron JA, Walker VE, Swenberg JA. Vinyl chloride-induced DNA adducts. II. Formation and persistence of 7-(2'-oxoethyl) guanine and $N^{2}$,3-ethenoguanine in rat tissue DNA. Carcinogenesis. 1990;11:1287-92.

45. Sodum RS, Chung FL. 1, $N^{2}$-Ethenodeoxyguanosine as a potential marker for DNA adducts formation by trans-4-hydroxy-2-nonenal. Cancer Res. 1988;48: 320-3.

46. El Ghissassi F, Barbin A, Nair J, Bartsch H. Formation of 1, $N^{6}$ ethenoadenine and $3, N^{4}$-ethenocytosine by lipid peroxidation products and nucleic acid bases. Chem Res Toxicol. 1995;8:278-83. https://doi. org/10.1021/tx00044a013.

47. Chung FL, Chen HJC, Nath RG. Lipid peroxidation as a potential endogenous source for the formation of exocyclic DNA adducts. Carcinogenesis. 1996;17(10):2105-11. https://doi.org/10.1093/carcin/17.1 0.2105 .

48. Bartsch $\mathrm{H}$. Hunting for electrophiles that harm human DNA: Frits Sobels award lecture. Mutagenesis. 2002;17(4):281-7. https://doi.org/10.1093/muta ge/17.4.281.

49. Petrova KV, Jalluri RS, Kozekov ID, Rizzo CJ. Mechanism of 1,N2-etheno-2'deoxyguanosine formation from epoxyaldehydes. Chem Res Toxicol. 2007: 20(11):1685-92. https://doi.org/10.1021/tx7001433.

50. Petrova KV, Stec DF, Voehler M, Rizzo CJ. Synthesis of the four stereoisomers of 2,3-epoxy-4-hydroxynonanal and their reactivity with deoxyguanosine. Org Biomol Chem. 2011;9(6):1960-71. https://doi.org/10.1039/C0OB00546K.

51. Sodum RS, Chung FL. Structural characterization of adducts formed in the reaction of 2,3-epoxy-4-hydroxynonanal with deoxyguanosine. Chem Res Toxicol. 1989;2:23-8

52. Chen HJC, Chung FL. Epoxidation of trans-4-hydroxy-2-nonenal by fatty acid hydroperoxides and hydrogen peroxide. Chem Res Toxicol. 1996;9(1):30612. https://doi.org/10.1021/tx9501389.

53. Jian W, Lee SH, Arora JS, Silva Elipe MV, Blair IA. Unexpected formation of etheno-2'-deoxyguanosine adducts from 5(S)-hydroperoxyeicosatetraenoic acid: evidence for a bis-hydroperoxide intermediate. Chem Res Toxicol. 2005;18(3):599-610. https://doi.org/10.1021/tx049693d.

54. Lee SH, Arora JA, Oe T, Blair IA. 4-Hydroperoxy-2-nonenal-induced formation of 1, $N^{2}$-etheno-2'-deoxyguanosine adducts. Chem Res Toxicol. 2005;18(4): 780-6. https://doi.org/10.1021/tx0497088.

55. Yang IY, Hashimoto K, de Wind N, Blair IA, Moriya M. Two distinct translesion synthesis pathways across a lipid peroxidation-derived DNA adduct in mammalian cells. J Biol Chem. 2009;284(1):191-8.

56. Fernandes $\mathrm{PH}$, Wang $\mathrm{H}$, Rizzo CJ, Lloyd RS. Site-specific mutagenicity of stereochemically defined $1, N^{2}$-deoxyguanosine adducts of trans-4hydroxynonenal in mammalian cells. Environ Mol Mutagen. 2003:42(2):68-74.

57. Christov PP, Petrova KV, Shanmugam G, Kozekov ID, Kozekova A, Guengerich FP, et al. Comparison of the in vitro replication of the 7-(2oxoheptyl)-1, $N^{2}$-etheno-2'-deoxyguanosine and $1, N^{2}$-etheno-2'- 
deoxyguanosine lesions by Sulfolobus solfataricus P2 DNA polymerase IV (Dpo4). Chem Res Toxicol. 2010;23(8):1330-41. https://doi.org/10.1021/ tx100082e.

58. Banerjee S, Christov PP, Kozekova A, Rizzo CJ, Egli M, Stone MP. Replication bypass of the trans-4-hydroxynonenal-derived $(6 S, 8 R, 11 S)-1, N^{2}$ deoxyguanosine DNA adduct by the Sulfolobus solfataricus DNA polymerase IV. Chem Res Toxicol. 2012;25(2):422-35. https://doi.org/10.1021/tx200460j.

59. Huang H, Wang H, Qi N, Lloyd RS, Rizzo CJ, Stone MP. The stereochemistry of trans-4-hydroxynonenal-derived exocyclic $1, N^{2}-2^{\prime}$-deoxyguanosine adducts modulates formation of interstrand cross-links in the $5^{\prime}-\mathrm{CpG}-3^{\prime}$ sequence. Biochemistry. 2008;47(44):11457-72. https://doi.org/10.1021/ bi8011143.

60. Stone MP, Cho YJ, Huang H, Kim HY, Kozekov ID, Kozekova A, et al. Interstrand DNA cross-links induced by $a, \beta$-unsaturated aldehydes derived from lipid peroxidation and environmental sources. Acc Chem Res. 2008; 41(7):793-804.

61. De Bont R, van Larebeke N. Endogenous DNA damage in humans: a review of quantitative data. Mutagenesis. 2004;19(3):169-85. https://doi.org/10.1 093/mutage/geh025.

62. Watson WP, Aston JP, Barlow T, Crane AE, Potter D, Brown T. Detection of $1, N^{6}$-etheno-2'-deoxyadenosine and $3, N^{4}$-etheno-2'-deoxycytidine occurring endogenously in DNA. IARC Sci Publ (Int Agency Res Cancer) (Lyon). 1999; 150:63-73.

63. Guichard Y, El Ghissassi F, Nair J, Bartsch H, Barbin A. Formation and accumulation of DNA ethenobases in adult Sprague-Dawley rats exposed to vinyl chloride. Carcinogenesis. 1996;17(8):1553-9. https://doi.org/10.1093/ca rcin/17.8.1553

64. Morinello EJ, Ham AJ, Ranasinghe A, Nakamura J, Upton PB, Swenberg JA. Molecular dosimetry and repair of $N^{2}, 3$-ethenoguanine in rats exposed to vinyl chloride. Cancer Res. 2002;62(18):5189-95.

65. Morinello EJ, Ham AJL, Ranasinghe A, Sangaiah R, Swenberg JA. Simultaneous quantitation of $N^{2}, 3$-ethenoguanine and $1, N^{2}$-ethenoguanine with an immunoaffinity/gas chromatography/high-resolution mass spectrometry assay. Chem Res Toxciol. 2001;14(3):327-34. https://doi.org/1 $0.1021 / \mathrm{t} \times 0002076$

66. Yen TY, Christova-Gueoguieva NI, Scheller N, Holt S, Swenberg JA, Charles MJ. Quantitative analysis of the DNA adduct $N^{2}, 3$-ethenoguanine using liquid chromatography/electrospray ionization mass spectrometry. J Mass Spectrom. 1996;31:1271-6.

67. Paiano V, Maertens L, Guidolin V, Yang J, Balbo S, Hecht SS. Quantitative liquid chromatography-nanoelectrospray ionization-high-resolution tandem mass spectrometry analysis of acrolein-DNA adducts and etheno-DNA adducts in oral cells from cigarette smokers and nonsmokers. Chem Res Toxciol. 2020;33(8):2197-207. https://doi.org/10.1021/acs.chemrestox. 0c00223.

68. Chen HC, Chiang L-C, Tseng M-C, Zhang LL, Ni J, Chung F-L. Detection and quantification of $1, N^{6}$-ethenoadenine in human placental DNA by mass spectrometry. Chem Res Toxciol. 1999;12:1119-26.

69. Doerge DR, Churchwell MI, Fang JL, Beland FA. Quantification of ethenoDNA adducts using liquid chromatography, on-line sample processing, and electrospray tandem mass spectrometry. Chem Res Toxciol. 2000;13(12): 1259-64. https://doi.org/10.1021/tx0001575.

70. Kadlubar FF, Anderson KE, Häussermann S, Lang NP, Barone GW, Thompson PA, et al. Comparison of DNA adduct levels associated with oxidative stress in human pancreas. Mutat Res. 1998;405(2):125-33. https://doi.org/10.1016/ s0027-5107(98)00129-8.

71. Chen HJ, Chiu WL. Association between cigarette smoking and urinary excretion of $1, N^{2}$-ethenoguanine measured by isotope dilution liquid chromatography-electrospray ionization/tandem mass spectrometry. Chem Res Toxciol. 2005;18(10):1593-9. https://doi.org/10.1021/tx050145p.

72. Guengerich FP, Crawford WM Jr, Watanabe PG. Activation of vinyl chloride to covalently bound metabolites: roles of 2-chloroethylene oxide and 2chloroacetaldehyde. Biochemistry. 1979;18(23):5177-82. https://doi.org/10.1 021/bi00590a023.

73. Guengerich FP, Persmark M. Mechanism of formation of ethenoguanine adducts from 2-haloacetaldehydes: ${ }^{13} \mathrm{C}$-labeling patterns with 2bromoacetaldehyde. Chem Res Toxciol. 1994;7(2):205-8. https://doi.org/10.1 021/tx00038a014.

74. Kusmierek JT, Singer B. Chloroacetaldehyde-treated ribo- and deoxyribopolynucleotides. 1. Reaction products. Biochemistry. 1982;21: 5717-22.
75. Golding BT, Slaich PK, Kennedy G, Bleasdale C, Watson WP. Mechanisms of formation of adducts from reactions of glycidaldehyde with 2'deoxyguanosine and/or guanosine. Chem Res Toxciol. 1996;9(1):147-57. https://doi.org/10.1021/tx950057c.

76. Vogt N, Marrot L, Rousseau N, Malfoy B, Leng M. Chloroacetaldehyde reacts with Z-DNA. J Mol Biol. 1988;201:773-6.

77. Sági J, Perry A, Hang B, Singer B. Differential destabilization of the DNA oligonucleotide double helix by a T.G mismatch, 3,N $N^{4}$-ethenocytosine, $3, N^{4}$ ethanocytosine, or an 8-(hydroxymethyl)-3, $N^{4}$-ethenocytosine adduct incorporated into the same sequence contexts. Chem Res Toxciol. 2000; 13(9):839-45. https://doi.org/10.1021/tx000040g.

78. Leonard GA, McAuley-Hecht KE, Gibson NJ, Brown T, Watson WP, Hunter WN. Guanine-1, $N^{6}$-ethenoadenine base pairs in the crystal structure of $d$ (CGCGAATT)(EdA)GCG. Biochemistry. 1994;33:4755-61.

79. Freisinger E, Fernandes A, Grollman AP, Kisker C. Crystallographic characterization of an exocyclic DNA adduct: $3, N^{4}$-etheno-2'-deoxycytidine in the dodecamer 5'-CGCGAATIECGCG-3'. J Mol Biol. 2003;329(4):685-97.

80. Cullinan D, Korobka A, Grollman AP, Patel DJ, Eisenberg M, de los Santos C. NMR solution structure of an oligodeoxynucleotide duplex containing the exocyclic lesion $3, N^{4}$-etheno-2'-deoxycytidine opposite thymidine: comparison with the duplex containing deoxyadenosine opposite the adduct. Biochemistry. 1996;35(41):13319-27. https://doi.org/10.1021/bi9605705.

81. Korobka A, Cullinan D, Cosman M, Grollman AP, Patel DJ, Eisenberg M, et al. Solution structure of an oligodeoxynucleotide duplex containing the exocyclic lesion $3, N^{4}$-etheno-2'-deoxycytidine opposite 2'-deoxyadenosine, determined by NMR spectroscopy and restrained molecular dynamics. Biochemistry. 1996;35:13310-8.

82. Cullinan D, Johnson F, de los Santos C. Solution structure of an 11-mer duplex containing the $3, N^{4}$-ethenocytosine adduct opposite $2^{\prime}$ deoxycytidine: implications for the recognition of exocyclic lesions by DNA glycosylases. J Mol Biol. 2000;296(3):851-61. https://doi.org/10.1006/jmbi.1 999.3490.

83. Cullinan D, Eisenberg M, de los Santos C. Solution structures of DNA duplexes containing the exocyclic lesion $3, N^{4}$-etheno-2'-deoxycytidine. IARC Scientific Publications (Int Agency Res Cancer, Lyon). 1999;(150):179-89.

84. Cullinan D, Johnson F, Grollman AP, Eisenberg M, de los Santos C. Solution structure of a DNA duplex containing the exocyclic lesion 3, $N^{4}$-etheno-2'deoxycytidine opposite 2'-deoxyguanosine. Biochemistry. 1997;36(39): 11933-43. https://doi.org/10.1021/bi9705725.

85. Kouchakdjian M, Eisenberg M, Yarema K, Basu A, Essigmann J, Patel DJ. NMR studies of the exocyclic 1, $N^{6}$-ethenodeoxyadenosine adduct ( $(\mathrm{dA})$ opposite thymidine in a DNA duplex. Nonplanar alignment of $\varepsilon d A$ (anti) and dT (anti) at the lesion site. Biochemistry. 1991;30(7):1820-8. https://doi.org/10.1021/ bi00221a014.

86. de los Santos C, Kouchakdjian M, Yarema K, Basu A, Essigmann J, Patel DJ. NMR studies of the exocyclic $1, N^{6}$-ethenodeoxyadenosine adduct $(\varepsilon d A)$ opposite deoxyguanosine in a DNA duplex. $\varepsilon \mathrm{dA}($ syn) $\mathrm{dG}$ (anti) pairing at the lesion site. Biochemistry. 1991;30:1828-35.

87. Shanmugam G, Goodenough AK, Kozekov ID, Guengerich FP, Rizzo CJ, Stone MP. Structure of the $1, N^{2}$-etheno-2'-deoxyguanosine adduct in duplex DNA at pH 8.6. Chem Res Toxciol. 2007;20(11):1601-11. https://doi.org/10.1 021/tx7001788.

88. Shanmugam G, Kozekov ID, Guengerich FP, Rizzo CJ, Stone MP. Structure of the $1, N^{2}$-ethenodeoxyguanosine adduct opposite cytosine in duplex DNA: Hoogsteen base pairing at pH 5.2. Chem Res Toxciol. 2008;21(9):1795-805. https://doi.org/10.1021/tx8001466.

89. Shanmugam G, Kozekov ID, Guengerich FP, Rizzo CJ, Stone MP. Structure of the $1, N^{2}$-etheno-2'-deoxyguanosine lesion in the $3^{\prime}-\mathrm{G}(\varepsilon \mathrm{dG}) \mathrm{T}-5^{\prime}$ sequence opposite a one-base deletion. Biochemistry. 2010;49(12):2615-26. https://doi. org/10.1021/bi901516d.

90. Zang H, Goodenough AK, Choi JY, Irimia A, Loukachevitch LV, Kozekov ID, et al. DNA adduct bypass polymerization by Sulfolobus solfataricus DNA polymerase Dpo4: Analysis and crystal structures of multiple base pair substitution and frameshift products with the adduct $1, N^{2}$-ethenoguanine. J Biol Chem. 2005;280(33):29750-64. https://doi.org/10.1074/jbc.M504756200.

91. Calabretta A, Leumann CJ. Base pairing and miscoding properties of $1, N^{6}$ ethenoadenine- and $3, N^{4}$-ethenocytosine-containing RNA oligonucleotides. Biochemistry. 2013;52(11):1990-7. https://doi.org/10.1021/bi400116y.

92. Loechler EL, Green CL, Essigmann JM. In vivo mutagenesis by $\mathrm{O}^{6}$ methylguanine built into a unique site in a viral genome. Proc Natl Acad Sci U S A. 1984;81:6271-5. 
93. Akasaka S, Guengerich FP. Mutagenicity of site-specifically located $1, N^{2}$ ethenoguanine in Chinese hamster ovary cell chromosomal DNA. Chem Res Toxciol. 1999;12(6):501-7. https://doi.org/10.1021/tx980259j.

94. Furge LL, Guengerich FP. Explanation of pre-steady-state kinetics and decreased burst amplitude of HIV-1 reverse transcriptase at sites of modified DNA bases with an additional, nonproductive enzyme-DNAnucleotide complex. Biochemistry. 1999;38(15):4818-25. https://doi.org/10.1 021/bi982163u.

95. Choi J-Y, Chowdhury G, Zang H, Angel KC, Vu CC, Peterson LA, et al. Translesion synthesis across $O^{6}$-alkylguanine DNA adducts by recombinant human DNA polymerases. J Biol Chem. 2006;281(50):38244-56. https://doi. org/10.1074/jbc.M608369200

96. Christov PP, Chowdhury G, Garmendia CA, Wang F, Stover JS, Elmquist CE, et al. The C8-2'-deoxyguanosine adduct of 2-amino-3-methylimidazo[1,2-d] naphthalene, a carbocyclic analogue of the potent mutagen 2-amino-3methylimidazo[4,5- $f$ quinoline, is a block to replication in vitro. Chem Res Toxciol. 2010;23(6):1076-88. https://doi.org/10.1021/tx100053n.

97. Chowdhury G, Guengerich FP. Liquid chromatography-mass spectrometry analysis of DNA polymerase reaction products. Curr Prot Nucleic Acid Chem. 2011. https://doi.org/10.1002/0471142700.nc0716s47 Chapter 7:Unit 7 16 11-11.

98. Delaney JC, Essigmann JM. Biological properties of single chemical-DNA adducts: a twenty year perspective. Chem Res Toxciol. 2008;21(1):232-52. https://doi.org/10.1021/tx700292a.

99. Chang SC, Fedeles BI, Wu J, Delaney JC, Li D, Zhao L, et al. Next-generation sequencing reveals the biological significance of the $N^{2}, 3$-ethenoguanine lesion in vivo. Nucleic Acids Res. 2015;43(11):5489-500. https://doi.org/10.1 093/nar/gkv243.

100. Beese LS, Berbyshire V, Steitz TA. Structure of DNA polymerase I Klenow fragment bound to duplex DNA. Science. 1993;260(5106):352-5. https://doi. org/10.1126/science.8469987

101. Wang F, Yang W. Structural insight into translesion synthesis by DNA Pol II. Cell. 2009;139(7):1279-89. https://doi.org/10.1016/j.cell.2009.11.043.

102. Johnson MK, Kottur J, Nair DT. A polar filter in DNA polymerases prevents ribonucleotide incorporation. Nucleic Acids Res. 2019;47(20):10693-705. https://doi.org/10.1093/nar/gkz792.

103. Warren JJ, Forsberg $L$, Beese LS. The structural basis for the mutagenicity of 06-methyl-guanine lesions. Proc Natl Acad Sci U S A. 2006;103(52):19701-6. https://doi.org/10.1073/pnas.0609580103.

104. Eoff RL, Irimia A, Egli M, Guengerich FP. Sulfolobus solfataricus DNA polymerase Dpo4 is partially inhibited by "wobble" pairing between $O^{6}$ methylguanine and cytosine, but accurate bypass is preferred. J Biol Chem. 2007;282(2):1456-67. https://doi.org/10.1074/jbc.M609661200.

105. Choi J-Y, Zang H, Angel KC, Kozekov ID, Goodenough AK, Rizzo CJ, et al. Translesion synthesis across $1, N^{2}$-ethenoguanine by human DNA polymerases. Chem Res Toxciol. 2006;19(6):879-86. https://doi.org/10.1021/tx060051v.

106. Ghodke PP, Mali JR, Patra A, Rizzo CJ, Guengerich FP, Egli M. Enzymatic bypass and structural basis of miscoding opposite the DNA adduct $1, N^{2}$ ethenodeoxyguanosine by human DNA translesion polymerase $\eta$. J Biol Chem. 2021;296:100642. https://doi.org/10.1016/j.jbc.2021.100642. Online ahead of print.

107. Zhao L, Christov PP, Kozekov ID, Pence MG, Pallan PS, Rizzo CJ, et al. Replication of $N^{2}$,3-ethenoguanine by DNA polymerases. Angew Chem Int Ed. 2012;51(22):5466-9. https://doi.org/10.1002/anie.201109004.

108. Zhao L, Pence MG, Christov PP, Wawrzak Z, Choi J-Y, Rizzo CJ, et al. Basis of miscoding of the DNA adduct $N^{2}, 3$-ethenoguanine by human $Y$-family DNA polymerases. J Biol Chem. 2012;287(42):35516-26. https://doi.org/10.1074/ jbc.M112.403253.

109. Zhang W, Johnson F, Grollman AP, Shibutani S. Miscoding by the exocyclic and related DNA adducts 3,N $N^{4}$-etheno-2'-deoxycytidine, 3,N $N^{4}$-ethano-2'deoxycytidine, and 3-(2-hydroxyethyl)-2'-deoxyuridine. Chem Res Toxciol. 1995:8(1):157-63. https://doi.org/10.1021/tx00043a021.

110. Shibutani S, Suzuki N, Matsumoto Y, Grollman AP. Miscoding properties of $3, N^{4}$-etheno-2'-deoxycytidine in reactions catalyzed by mammalian DNA polymerases. Biochemistry. 1996;35:14992-8.

111. Moriya M, Zhang W, Johnson F, Grollman AP. Mutagenic potency of exocyclic DNA adducts: marked differences between Escherichia coli and simian kidney cells. Proc Natl Acad Sci U S A. 1994;91(25):11899-903. https://doi.org/10.1073/pnas.91.25.11899.

112. Singer B, Abbott LG, Spengler SJ. Assessment of mutagenic efficiency of two carcinogen-modified nucleosides, $1, N^{6}$-ethenodeoxyadenosine and $\mathrm{O}^{4}$ - methyldeoxythymidine, using polymerases of varying fidelity. Carcinogenesis. 1984;5:1165-71.

113. Litinski V, Sagi CJ, Singer B. Sequence context is an important determinant in the mutagenic potential of $1, N^{6}$-ethenodeoxyadenosine $(\varepsilon A)$ : formation of $\varepsilon A$ basepairs and elongation in defined templates. Carcinogenesis. 1997; 18(8):1609-15. https://doi.org/10.1093/carcin/18.8.1609.

114. Pandya GA, Moriya M. 1,N6-Ethenodoexyadenosine, a DNA adduct highly mutagenic in mammalian cells. Biochemistry. 1996;35(35):11487-92. https:// doi.org/10.1021/bi960170h.

115. Levine RL, Yang I-Y, Hossain M, Pandya GA, Grollman AP, Moriya M. Mutagenesis induced by a single $1, N^{6}$-ethenodeoxyadenosine adduct in human cells. Cancer Res. 2000;60:4098-104.

116. Tolentino JH, Burke TJ, Mukhopadhyay S, McGregor WG, Basu AK. Inhibition of DNA replication fork progression and mutagenic potential of $1, N^{6}$ ethenoadenine and 8-oxoguanine in human cell extracts. Nucleic Acids Res. 2008;36(4):1300-8. https://doi.org/10.1093/nar/gkm1157.

117. Levine RL, Miller $H$, Grollman A, Ohashi E, Ohmori $H$, Masutani $C$, et al. Translesion DNA synthesis catalyzed by human pol $\eta$ and pol $\mathrm{K}$ across $1, N^{6}$ ethenodeoxyadenosine. J Biol Chem. 2001;276(22):18717-21. https://doi. org/10.1074/jbc.M102158200.

118. Patra A, Su Y, Zhang Q, Johnson KM, Guengerich FP, Egli M. Structural and kinetic analysis of miscoding opposite the DNA adduct $1, N^{6}$ ethenodeoxyadenosine by human translesion DNA polymerase $\eta$. J Biol Chem. 2016;291(27):14134-45. https://doi.org/10.1074/jbc.M116.732487.

119. Nair DT, Johnson RE, Prakash L, Prakash S, Aggarwal AK. Hoogsteen base pair formation promotes synthesis opposite the $1, N^{6}$ ethenodeoxyadenosine lesion by human DNA polymerase ı. Nat Struct Mol Biol. 2006;13(7):619-25. https://doi.org/10.1038/nsmb1118.

120. Langouët S, Müller M, Guengerich FP. Misincorporation of dNTPS opposite 1, $N^{2}$-ethenoguanine and 5,6,7,9-tetrahydro-7-hydroxy-9-oxoimidazo[1,2-a] purine in oligonucleotides by Escherichia coli polymerases I exo ${ }^{-}$and II exo- ${ }^{-}$T7 polymerase exo ${ }^{-}$, human immunodeficiency virus-1 reverse transcriptase, and rat polymerase $\beta$. Biochemistry. 1997;36(20):6069-79. https://doi.org/10.1021/bi962526v.

121. Langouët S, Mican AN, Müller M, Fink SP, Marnett LJ, Muhle SA, et al. Misincorporation of nucleotides opposite five-membered exocyclic ring guanine derivatives by Escherichia coli polymerases in vitro and in vivo: 1, $N^{2}$. ethenoguanine, 5,6,7,9-tetrahydro-9-oxoimidazo[1,2-a] purine, and 5,6,7,9tetrahydro-7-hydroxy-9-oxoimidazo[1,2-a]purine. Biochemistry. 1998;37(15): 5184-93. https://doi.org/10.1021/bi972327r.

122. Kusmierek JT, Folkman W, Singer B. Synthesis of $N^{2}, 3-$ ethenodeoxyguanosine, $N^{2}, 3$-deoxyguanosine $5^{\prime}$-phosphate, and $N^{2}, 3-$ ethenodeoxyguanosine $5^{\prime}$-triphosphate. Stability of the glycosyl bond in the monomer and in poly (dG,edG-dC). Chem Res Toxciol. 1989;2(4):230-3. https://doi.org/10.1021/tx00010a003.

123. Singer B, Spengler SJ, Chavez F, Kusmierek JT. The vinyl chloride-derived nucleoside, $N^{2}$,3-ethenoguanosine, is a highly efficient mutagen in transcription. Carcinogenesis. 1987;8:745-7.

124. Singer B, Kusmierek JT, Folkman W, Chavez F, Dosanjh MK. Evidence for the mutagenic potential of the vinyl chloride induced adduct, $N^{2}$,3-ethenodeoxyguanosine, using a site-directed kinetic assay. Carcinogenesis. 1991; 12(4):745-7. https://doi.org/10.1093/carcin/12.4.745.

125. Lee $S$, Bowman BR, Ueno $Y$, Wang $S$, Verdine GL. Synthesis and structure of duplex DNA containing the genotoxic nucleobase lesion $N^{7}$-methylguanine. J Am Chem Soc. 2008;130(35):11570-1.

126. Marion MJ, Froment O, Trépo C. Activation of Ki-ras gene by point mutation in human liver angiosarcoma associated with vinyl chloride exposure. Mol Carcinog. 1991;4(6):450-4. https://doi.org/10.1002/mc.2940040607.

127. Swenberg JA, Fedtke N, Ciroussel F, Barbin A, Bartsch H. Etheno adducts formed in DNA of vinyl chloride-exposed rats are highly persistent in liver. Carcinogenesis. 1992;13:727-9.

128. Oesch F, Adler S, Rettelbach R, Doerjer G. Repair of etheno DNA adducts by $\mathrm{N}$-glycosylases. In: Singer B, Bartsch H, editors. The Role of Cyclic Nucleic Acid Adducts in Carcinogenesis \& Mutagenesis, vol. 70. Lyon: IARC Sci Publ; 1986. p. 373-9.

129. Rydberg B, Dosanjh MK, Singer B. Human cells contain protein specifically binding to a single $1, N^{6}$-ethenoadenine in a DNA fragment. Proc Natl Acad Sci U S A. 1991;88(15):6839-42. https://doi.org/10.1073/pnas.88.15.6839.

130. Rydberg B, Qiu ZH, Dosanjh MK, Singer B. Partial purification of a human DNA glycosylase acting on the cyclic carcinogen adduct $1, N^{6}$ ethenodeoxyadenosine. Cancer Res. 1992;52:1377-9. 
131. Singer B, Antoccia A, Basu AK, Dosanjh MK, Fraenkelconrat $H$, Gallagher PE, et al. Both purified human $1, N^{6}$-ethenoadenine-binding protein and purified human 3-methyladenine-DNA glycosylase act on 1,N6-ethenoadenine and 3-methyladenine. Proc Natl Acad Sci U S A. 1992;89:9386-90.

132. Dosanjh MK, Chenna A, Kim E, Fraenkel-Conrat H, Samson L, Singer B. All four known cyclic adducts formed in DNA by the vinyl chloride metabolite chloroacetaldehyde are released by a human DNA glycosylase. Proc Nat Acad Sci U S A. 1994:91(3):1024-8. https://doi.org/10.1073/pnas.91.3.1024.

133. Hang B, Chenna A, Rao S, Singer B. $1, N^{6}$-Ethenoadenine and $3, N^{4}$ ethenocytosine are excised by separate human DNA glycosylases. Carcinogenesis. 1996;17:155-7.

134. Saparbaev M, Langouet S, Privezentzev CV, Guengerich FP, Cai H, Elder RH, et al. $1, N^{2}$-Ethenoguanine, a mutagenic DNA adduct, is a primary substrate of Escherichia coli mismatch-specific uracil-DNA glycosylase and human alkylpurine-DNA-N-glycosylase. J Biol Chem. 2002;277(30):26987-93. https:// doi.org/10.1074/jbc.M111100200.

135. Guliaev AB, Singer B, Hang B. Chloroethylnitrosourea-derived ethano cytosine and adenine adducts are substrates for Escherichia coli glycosylases excising analogous etheno adducts. DNA Repair. 2004;3(10):1311-21. https://doi.org/10.1016/j.dnarep.2004.04.015.

136. Prorok P, Saint-Pierre C, Gasparutto D, Fedorova OS, Ishchenko AA, Leh H, et al. Highly mutagenic exocyclic DNA adducts are substrates for the human nucleotide incision repair pathway. PLoS One. 2012;7(12):e51776. https://doi.org/10.1371/journal.pone.0051776.

137. Chaim IA, Gardner A, Wu JE, Iyama T, Wilson DM, Samson LD. A novel role for transcription-coupled nucleotide excision repair for the in vivo repair of 3,N $N^{4}$-ethenocytosine. Nucleic Acids Res. 2017;45(6):3242-52. https://doi.org/1 0.1093/nar/gkx015.

138. Delaney JC, Smeester L, Wong C, Frick LE, Taghizadeh K, Wishnok JS, et al. AlkB reverses etheno DNA lesions caused by lipid oxidation in vitro and in vivo. Nat Struct Mol Biol. 2005;12(10):855-60.

139. Zdzalik D, Domanska A, Prorok P, Kosicki K, van den Born E, Falnes PO, et al. Differential repair of etheno-DNA adducts by bacterial and human AlkB proteins. DNA Repair. 2015;30:1-10. https://doi.org/10.1016/j.dnarep.2015.02.021.

140. Knutson CG, Rubinson EH, Akingbade D, Anderson CS, Stec DF, Petrova KV, et al. Oxidation and glycolytic cleavage of etheno and propano DNA base adducts. Biochemistry. 2009;48(4):800-9. https://doi.org/10.1021/bi801654j.

141. Caldecott KW. Ribose-an internal threat to DNA. Science. 2014;343(6168): 260-1. https://doi.org/10.1126/science.1248234.

142. Williams JS, Kunkel TA. Ribonucleotides in DNA: origins, repair and consequences. DNA Repair. 2014;19:27-37. https://doi.org/10.1016/j.dnarep.2 014.03.029.

143. Forslund JME, Pfeiffer A, Stojkovic G, Wanrooij PH, Wanrooij S. The presence of rNTPs decreases the speed of mitochondrial DNA replication. PLOS Genet. 2018;14(3):e1007315. https://doi.org/10.1371/journal.pgen.1007315.

144. Li Y, Breaker RR. Kinetics of RNA degradation by specific base catalysis of transesterification involving the 2'-hydroxyl group. J Am Chem Soc. 1999; 121(23):5364-72. https://doi.org/10.1021/ja990592p.

145. Evich M, Spring-Connell AM, Storici F, Germann MW. Structural impact of single ribonucleotide residues in DNA. Chembiochem. 2016;17(20):1968-77. https://doi.org/10.1002/cbic.201600385.

146. Ren M, Cheng Y, Duan Q, Zhou C. Transesterification reaction and the repair of embedded ribonucleotides in DNA are suppressed upon the assembly of DNA into nucleosome core particles dagger. Chem Res Toxciol. 2019;32(5): 926-34. https://doi.org/10.1021/acs.chemrestox.9b00059.

147. Klein HL. Genome instabilities arising from ribonucleotides in DNA. DNA Repair. 2017;56:26-32. https://doi.org/10.1016/j.dnarep.2017.06.004.

148. Nick McElhinny SA, Watts BE, Kumar D, Watt DL, Lundstrom EB, Burgers PM, et al. Abundant ribonucleotide incorporation into DNA by yeast replicative polymerases. Proc Natl Acad Sci U S A. 2010;107(11):4949-54. https://doi. org/10.1073/pnas.0914857107.

149. Yao NY, Schroeder JW, Yurieva O, Simmons LA, O'Donnell ME. Cost of rNTP/ dNTP pool imbalance at the replication fork. Proc Natl Acad Sci U S A. 2013; 110(32):12942-7. https://doi.org/10.1073/pnas.1309506110.

150. Pai CC, Kearsey SE. A critical balance: dNTPs and the maintenance of genome stability. Genes. 2017;8(2). https://doi.org/10.3390/genes8020057.

151. Clausen AR, Zhang S, Burgers PM, Lee MY, Kunkel TA. Ribonucleotide incorporation, proofreading and bypass by human DNA polymerase $\delta$. DNA Repair. 2013;12(2):121-7. https://doi.org/10.1016/j.dnarep.2012.11.006.

152. Reijns MA, Rabe $B$, Rigby RE, Mill $P$, Astell KR, Lettice LA, et al. Enzymatic removal of ribonucleotides from DNA is essential for mammalian genome integrity and development. Cell. 2012;149(5):1008-22. https://doi.org/10.101 6/j.cell.2012.04.011.

153. Kim N, Huang S-yN, Williams JS, Li YC, Clark AB, Cho J-E, et al. Mutagenic processing of ribonucleotides in DNA by yeast topoisomerase I. Science. 2011;332(6037):1561-4. https://doi.org/10.1126/science.1205016.

154. Cerritelli SM, Crouch RJ. RNase H2-RED carpets the path to eukaryotic RNase H2 functions. DNA Repair. 2019;84:102736. https://doi.org/10.1016/j.dnarep.2 019.102736.

155. Kellner $\mathrm{V}$, Luke B. Molecular and physiological consequences of faulty eukaryotic ribonucleotide excision repair. EMBO J. 2019:e102309. https://doi. org/10.15252/embj.2019102309.

156. Su Y, Egli M, Guengerich FP. Mechanism of ribonucleotide incorporation by human DNA polymerase n. J Biol Chem. 2016;291(8):3747-56. https://doi. org/10.1074/jbc.M115.706226.

157. Su Y, Egli M, Guengerich FP. Human DNA polymerase $\eta$ accommodates RNA for strand extension. J Biol Chem. 2017;292(44):18044-51. https://doi. org/10.1074/jbc.M117.809723.

158. Su Y, Ghodke PP, Egli M, Li L, Wang Y, Guengerich FP. Human DNA polymerase $\eta$ has reverse transcriptase activity in cellular environments. J Biol Chem. 2019;294(15):6073-81. https://doi.org/10.1074/jbc.RA119.007925.

159. Ghodke PP, Guengerich FP. Impact of $1, N^{6}$-ethenoadenosine, a damaged ribonucleotide in DNA, on translesion synthesis and repair. J Biol Chem. 2020;295(18):6092-107. https://doi.org/10.1074/jbc.RA120.012829.

\section{Publisher's Note}

Springer Nature remains neutral with regard to jurisdictional claims in published maps and institutional affiliations.
Ready to submit your research? Choose BMC and benefit from:

- fast, convenient online submission

- thorough peer review by experienced researchers in your field

- rapid publication on acceptance

- support for research data, including large and complex data types

- gold Open Access which fosters wider collaboration and increased citations

- maximum visibility for your research: over $100 \mathrm{M}$ website views per year

At BMC, research is always in progress.

Learn more biomedcentral.com/submissions 